\title{
Implementing forest landscape restoration under the Bonn Challenge: a systematic approach
}

\author{
John A. Stanturf ${ }^{1}$ (D) Michael Kleine $^{2} \cdot$ Stephanie Mansourian $^{3} \cdot$ John Parrotta $^{4} \cdot$ Palle Madsen $^{5} \cdot$ Promode Kant $^{6}$. \\ Janice Burns ${ }^{2} \cdot$ Andreas Bolte $^{7}$
}

Received: 30 July 2018 / Accepted: 4 April 2019 / Published online: 1 May 2019

(C) INRA and Springer-Verlag France SAS, part of Springer Nature 2019

\begin{abstract}
- Key message There is no one-size-fits-all way to successfully implement forest landscape restoration (FLR). Complex socio-ecological systems present challenges and opportunities that can best be met with a systematic framework for designing, planning, steering, and monitoring FLR projects to meet diverse needs. Project cycle management is an iterative, adaptive, hierarchical framework with recurring consultations among stakeholders that can enhance the likelihood of FLR success.
\end{abstract}

Keywords Bonn Challenge $\cdot$ Ecological integrity $\cdot$ Livelihoods $\cdot$ Governance $\cdot$ Project cycle management

\section{Introduction}

Interest in halting and reversing degradation and restoring landscapes is high, particularly forest landscapes; however, the normal issue attention cycle in public opinion and policy (Fig. 1) suggests that the commitment of policy makers will wane as they become aware of costs, complexity, the time needed for outcomes to be realized, and the lessening interest of the public and stakeholders (Downs 1972). The Bonn

Handling Editor: Laurent Bergès

Contribution of the co-authors John Stanturf developed the structure and wrote the initial draft manuscript. All authors contributed significantly to the manuscript.

This article is part of the topical collection on Forest Adaptation and Restoration under Global Change

John A. Stanturf

Drdirt48@gmail.com

Estonian University of Life Sciences, Tartu, Estonia

2 International Union of Forest Research Organizations, Vienna, Austria

3 Mansourian Consulting, Gingins, Switzerland

4 US Forest Service, Washington, DC, USA

5 Copenhagen University, Copenhagen, Denmark

6 Institute of Green Economy, Delhi, India

7 Thünen Institute for Forest Ecosystems, Eberswalde, Germany
Challenge and regional initiatives have mobilized political support to commence restoration on 150 million ha of forest landscapes by 2020 and 350 million ha by 2030 . Underlying the Bonn Challenge is the forest landscape restoration (FLR) approach that differs from a more eco-centric, ecological restoration in that equal priority is given to human livelihoods and biodiversity conservation (Mansourian 2005; Stanturf et al. 2014a). Although there appears to be general consensus on the broad principles of FLR (Besseau et al. 2018), little guidance exists on how to put these principles into operation (Stanturf 2015). Because FLR is relatively new, examples are lacking of successful long-term implementation that fully satisfy all FLR principles. While there are many practical but isolated examples of specific techniques and projects that illustrate FLR, implementation requires a more general systematic approach to how we manage and govern land, including organization of local, national, and global reward systems (Mansourian 2017; Pistorius and Freiberg 2014).

Resilience is one of the most important aspects of FLR; vigorous trees in ecologically stable ecosystems are a precondition for the delivery of ecosystem services from restored forests in changing environmental conditions (Spathelf et al. 2018). Extreme climatic events, altered climate means, and land use change (Liang et al. 2018; Stanturf 2015) and novel climate and disease scenarios (Aitken et al. 2008) are increasing the need for restoration. Insufficient consideration of future climate means and extremes will negatively affect resilience of restored landscapes (DeRose and Long 2014). While past experience offers hope, we cannot expect that natural 


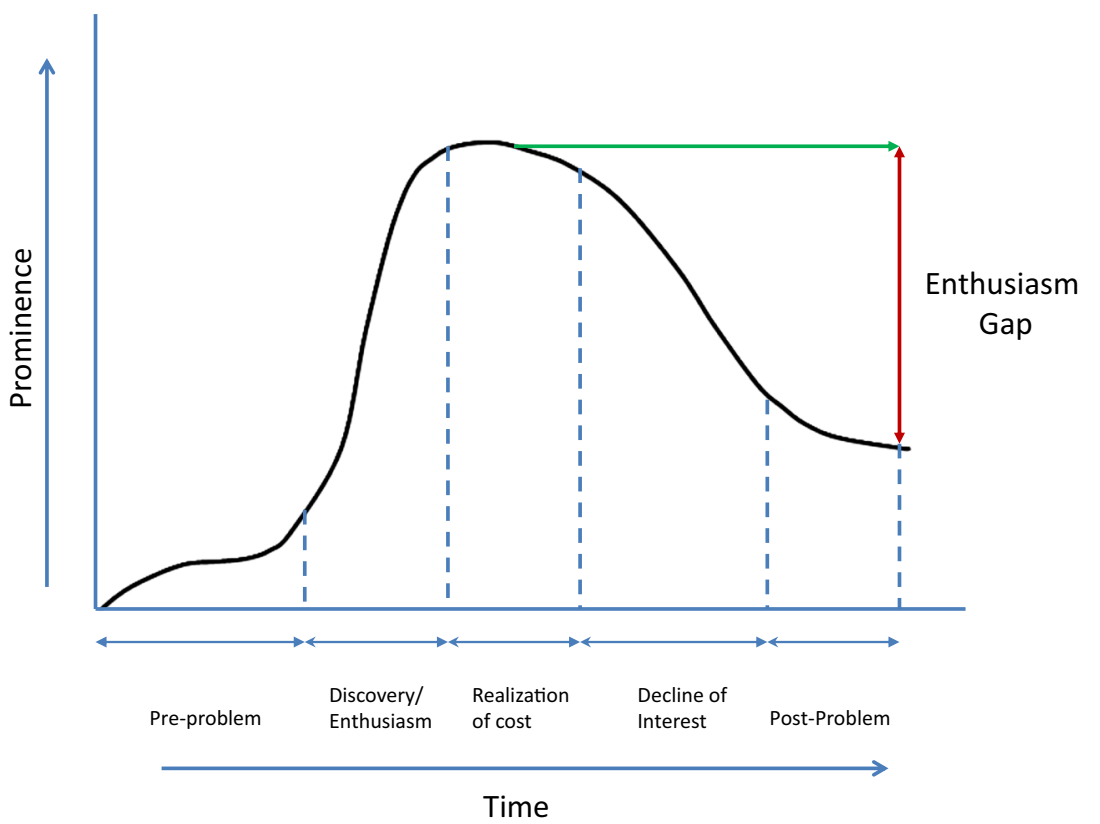

Fig. 1 The policy attention cycle, illustrating the waxing and waning of interest in an issue over time. The beginning of deforestation and forest degradation dates to pre-history, accelerating with the advent of agriculture (pre-problem stage). Recognition of the need for reversing deforestation and degradation probably date to the same time in prehistory but the development of forest landscape restoration (FLR) as a

processes and native species and provenances will provide optimal solutions powerful enough to meet all future needs.

Achieving meaningful success at restoring degraded landscapes will be costly in both financial and social terms. Critics argue that restoration takes too long, costs too much, and produces too few benefits to justify public or private expenditures (Verdone and Seidl 2017). While the costs of investments in restoration may appear to be high - particularly in the near term - these costs are typically very low when compared to the costs of inaction (e.g., IPBES 2018; UNCCD 2017). Embedding restoration objectives in a broader development agenda - such as attainment of the sustainable development goals (SDGs) - may be important for maintaining support and securing the financial resources needed for restoration programs and activities (Mansourian 2018). Restoration can contribute to the attainment of the SDGs, in particular those related to food security, poverty alleviation, water, human health, and biodiversity conservation (Mansourian 2018; Swamy et al. 2018). When international commitments are linked to accepted local goals and aspirations, the chances of achieving restoration targets are enhanced. But, unleashing large-scale restoration may require changes to policy frameworks, tenure systems, and institutional arrangements, in other words challenging business as usual (Mansourian 2017; Reinecke and Blum 2018).

Overcoming the "enthusiasm gap" (Fig. 1) that could develop as the Bonn Challenge matures requires at a minimum, successful FLR implementation following a consistent policy issue (stage 2) began with academic attention to ecological restoration in the 1970s and formation of the Society for Ecological Restoration in 1988. Formal definition of FLR dates to 2000. Currently, FLR is in stage $2 / 3$. If the normal cycle prevails and interests decline (stages 3-4), the need for FLR will not decline but a gap in enthusiasm may develop (after Downs 1972)

strategic program, so it is useful to take stock of what tools we already have. Integrated landscape approaches (Freeman et al. 2015; Kusters et al. 2017) such as FLR are prominent in efforts to reverse past socio-ecological damage. Landscapes are multi-functional; they are not defined just by what is found within a geographical space (Oliver et al. 2012; van Oosten 2013). Besides internal dynamics, landscapes are influenced by external factors such as migration, global trade, consumer preferences, international agreements, investors, and climate change (Grau and Aide 2008; Martín-López et al. 2017).

Implementing FLR is challenging because of the need to consider context: political, economic, social, as well as biophysical, in balancing competing interests and differing priorities for livelihoods versus biodiversity (Maron et al. 2012). On the one hand, in contexts such as protected areas, biodiversity conservation may take precedence over immediate human needs and ecological restoration plays a central role (Keenleyside et al. 2012). Nevertheless, people living in and around protected areas often need compensation for loss of livelihoods in order to avoid further encroachment and for restoration to be sustainable over the long term (MacKay and Caruso 2004; Wells and McShane 2004). On the other hand, many landscapes in need of restoration are a mosaic of different land uses and that may tip the scales toward meeting human livelihood needs in restoration decisions, for example by planting non-native species for fuelwood (Kegode et al. 2017; Tesfaye et al. 2015). A strength of FLR as a landscape approach is the opportunity for compromise and sub- 
optimization of some objectives, for example improving species diversity within a production-oriented landscape, but never quite reaching the diversity of a pure conservation area. Another example of sub-optimization might be planting slower-growing native species that sequester less carbon than faster-growing non-native species but provide better habitat for local wildlife (Lamb et al. 2012).

The objective of this paper is to review topics that need to be considered for successfully implementing FLR at multiple scales, under diverse ecological and socioeconomic conditions, where stakeholders have differing expectations for success. We set the stage with reflections from three welldocumented past experiences of large-scale restoration in Puerto Rico, Denmark, and South Korea, followed by an overview of some of the current global challenges to FLR implementation. Then, we suggest that likelihood of successful FLR implementation is enhanced by following the well-established methods of project cycle management (Battisti 2017; Khang and Moe 2008). We conclude by describing some future needs. Our key message is that there is no one-size-fits-all approach to FLR implementation, and the complexity of socio-ecological systems provides not only challenges but also opportunities for meeting diverse needs.

\section{Long-term experience of forest restoration}

Past restoration approaches based on simple methods have been successful (Stanturf 2016). Much restoration was accomplished by simply abandoning agriculture and allowing undisturbed, natural processes of recolonization. Most active approaches had singular objectives such as reducing soil erosion or restoring productive commercial forest plantations (Mansourian 2018; Stanturf et al. 2014b). While successful, these simple approaches may not be well adapted to today's complexity, including the increased uncertainties associated with climate change and its effects on ecosystems, human communities, and land management practices (Parrott and Meyer 2012; Puettmann 2014). Nevertheless, these examples typify the resilience of forest landscapes.

\subsection{Puerto Rico}

Puerto Rico provides many examples of passive and active restoration based on 75 years of continuous research in dry, moist, wet, and rain forest environments (Grau et al. 2003; Lugo and Helmer 2004). Research included species trials with over 400 native and non-native tree species. Passive restoration occurred as land was abandoned from active agriculture, either spontaneously or after government intervention. Sometimes, farmers were provided with commercial tree species to intercrop with food plants until canopy closure; farmers were then relocated (Robinson et al. 2014b).
Monitoring of native and plantation forest stands over 60 years provided information on the overstory growth and development of native species in the understory (Lugo 2000; Lugo 2018) and formed the basis for studies of stand dynamics, in particular the effects of hurricane disturbances (Lugo 2000). Continuous island-wide forest inventories conducted since 1982, analysis of land cover changes using air photos from the 1930s to the 1970s, and subsequently high-resolution satellite images have added to the understanding of landscape change (Martinuzzi et al. 2013). In 2017, Hurricanes Irma and Maria significantly damaged the island and reset forest dynamics.

\subsection{Denmark}

Denmark has a 200-year history of FLR, a story of forest cover losses and gains typical for land in the Northwest European lowland (Madsen et al. 2005). It is also a story of ecological disaster; large areas of degraded, unproductive heathland were created. Attempts at forest restoration in Denmark were similar to events elsewhere including heathland tracts of Northern Germany (Bradshaw 2004). Deforestation from shifting agriculture, grazing, and fire created a highly degraded landscape that needed non-native conifers for restoration; native broadleaves could not establish on the degraded heathlands (Madsen et al. 2005), and people needed wood for construction and fuel. Overgrazing and fire also destroyed the heather, exposing sandy soil to wind erosion. The dunes that formed sometimes covered houses and whole villages.

Because of harsh growing conditions, survival and growth of planted seedlings were low and only non-native conifers such as mountain pine (Pinus mugo Turra) could survive. Today, non-native species such as Douglas-fir (Pseudotsuga menziesii (Mirb.) Franco), Norway spruce (Picea abies (L.) Karst.), and Scots pine (Pinus sylvestris L.) support continuous cover forestry systems. The re-introduction of native broadleaves such as European beech (Fagus sylvatica L.) is occurring and managed in mixed, novel forests. Recent research is examining the potential contribution of species from the Caspian Forest in Iran (Stanturf et al. 2018). One lesson to draw from the Danish experience is the importance of citizen support. Although the restoration effort was led by philanthropic elites, there was mass support of the program on the basis of national pride and patriotism (Madsen et al. 2005).

\subsection{South Korea}

South Korea provides another example of FLR (Lee et al. 2015; Park and Youn 2017). The causes of deforestation in the Korean Peninsula were several: over-exploitation of forest resources for fuel (firewood and charcoal accounted for $62.5 \%$ of primary energy into the 1960s); illegal logging that 
occurred widely, mainly due to increasing poor population; expansion of agricultural lands (19\% increase in 1952-1968); and the Korean War (1950-1953) destroyed forests. The restoration example of South Korea is widely praised and relied on three factors, two of which are well known: the positive attitude of the people that favored the government-led reforestation program, which was re-enforced by economic incentives for income generation from community forestry, and overall economic growth of the nation that allowed the government to invest in reforestation (Park and Youn 2017). Critics, however, have also pointed to the largely top-down approach taken to restoration and to the possible displacement of deforestation and forest degradation to other countries.

The third factor in the success of reforesting South Korea, policy integration (Park and Youn 2017), has not received as much attention. Investment in the forestry sector was included in a series of coordinated national economic plans from 1967 to 1987 primarily for erosion control and conservation. Further, governmental agencies collaborated on energy policy to reduce pressure on the forest by substituting wood with coal briquettes, by remodeling house heating systems to use the briquettes, and by establishing fuelwood plantations. Illegal timber harvests were reduced by providing alternatives to local wood for housing construction. The Ministry of Agriculture and Forestry prohibited the use of timber for domestic purposes and limited permits for timber harvesting from private forests. The Ministry of Construction limited construction permits for housing, and the Ministry of Commerce and Industry liberalized timber imports and increased production and distribution of cement as a substitute of timber for construction. Increased enforcement of timber harvesting laws was made possible by moving the Korea Forest Service to the Ministry of Home Affairs in 1973 (until 1987), thereby giving them law enforcement responsibility.

\subsection{Lessons learned from these case studies}

Some key biological and social lessons can be gleaned from these examples. Restoration interventions, under either anthropogenic or non-anthropogenic control, can be successful. The level of soil degradation determines species composition, and introduced species can colonize without intervention. Protecting and restoring the soil is critical for facilitating restoration, particularly replenishment of soil organic matter. Natural processes, such as seed dispersal, colonization, and self-organization, are restoration assets which humans cannot replace (Lugo 1997; Lugo and Helmer 2004).

Novelty was a component; all species, native or non-native, played a role in restoration (e.g., Lugo and Erickson 2017). Planting monocultures (mahogany on private land in Puerto Rico or mountain pine in Denmark) achieved high levels of diversity over time as native species dispersed into plantations. Canopy closure was a key moment in the restoration trajectory (environmentally and biologically). Monitoring restored systems and allowing time for them to develop were necessary steps to ensure successful restoration.

Local and national support for restoration was critical for success. Popular support in Denmark was cast as a matter of national pride and patriotism. Similarly in South Korea, people approved of the government-driven restoration program backed by incentives and facilitated by overall economic growth. Government ministries reinforced restoration efforts by integrating policies, for example enforcing laws against illegal logging offset by imported wood to meet local needs (Park and Youn 2017). In Puerto Rico, government industrialization policies encouraged land abandonment, thereby reducing pressure on native forests and allowing deforested areas to recover (Grau et al. 2003). In all cases, these were long-term initiatives; today, however, faced with political enthusiasm and climate change, there is pressure to restore vast areas in a much shorter period.

\section{Global challenges for FLR}

Available evidence strongly suggests that FLR will be successful only when the underlying causes of deforestation and degradation (DeFries et al. 2010) are recognized and addressed (IPBES 2018; Robinson et al. 2014a), particularly unclear land tenure, governance and market failures, and lack of policy coordination (Mansourian 2017). Understanding, influencing, and shaping landscape governance is needed for successful FLR implementation, including notably engaging people at all levels, mechanisms by which people make decisions, tools used to facilitate decision-making, and structures to reach and implement those decisions (Mansourian 2017; Reinecke and Blum 2018).

Landscapes stretch over wide areas, crossing boundaries between administrative jurisdictions, possibly including several municipalities, counties, provinces, or transboundary regions between nations. The socio-ecological processes occurring in landscapes often are asynchronous with the political organization of state and sub-state governance units that may be rooted in historical developments such as colonialism. This asynchrony hampers the process of building strong and coherent institutions within the landscape (Reinecke and Blum 2018), leading to fragmented policies that do not match the multi-functionality of landscapes. Therefore, improving landscape governance means reconnecting the administratively fragmented landscapes and building bridges among actors and sectors operating on either side of a boundary without adding more layers of administration.

Viewpoints differ on some critical issues affecting FLR implementation, including preferences for top-down or bottom-up planning and priority setting (Cordell et al. 2017; Evans et al. 2018), potential of passive versus active 
restoration (Crouzeilles et al. 2017; Reid et al. 2018), and perceived need for exclusion of non-native species in favor of native species (Davis et al. 2011; Thomas et al. 2014). Too little attention has been given to planning long-term management of restored (or restoring) landscapes that will result in resilience in the face of changing climate, resistance to future degradation, and social benefit from provisioning various goods and services (Reid et al. 2017; Stanturf 2015).

\subsection{Meeting expectations}

Unmet expectations from FLR could contribute to waning enthusiasm for the Bonn Challenge. For example, because there is no vetting process for Bonn Challenge commitments, it may not be clear in a local context if projects to meet national commitments are really FLR, if the purported benefits will be realized or be realized by the most affected communities. Critics of the Bonn Challenge process have noted its focus on numerical targets (hectares) without sufficient consideration of the effectiveness (quality) of restoration projects (Brancalion and Chazdon 2017; Mansourian et al. 2017). Vague or conflicting ideas of what comprises successful restoration may arise in the absence of clear guidelines on what constitutes FLR. The FLR approach places great emphasis on participatory decision-making (Pistorius and Freiberg 2014; Sayer et al. 2013). As Reinecke and Blum (2018) conclude, however, FLR is unlikely to please everyone and who benefits will depend on who plans and implements FLR.

\subsection{Conceptual clarity}

Adding to the potential difficulty of unmet expectations is the lack of consensus on key concepts of FLR. Even the definition of forest is contentious with some arguing that a forest must be "natural," thereby excluding planted forests from such a definition (Chazdon et al. 2016; Putz and Redford 2010). At the other extreme, simply increasing forest cover with non-native species is not realistic either because of the loss of biodiversity and probably lack of livelihood enhancement (e.g., Zhai et al. 2014). Further, a narrow focus on "forests" defined as closed canopy systems will undervalue the contribution of woodlands and trees outside forests (van Noordwijk et al. 2008; Zomer et al. 2016). As well, a lack of trees in the landscape does not always indicate deforestation or degradation; it might indicate the presence of native grassland or savanna (Veldman et al. 2015). Unresolved, these conflicting notions and potentially unmet expectations may render FLR irrelevant over the long term.

Differing definitions of degradation have hampered identifying degraded areas in need of restoration (FAO 2011; IPBES 2018). Determining what is degradation is a subjective matter (Hobbs 2016); what is clear is that FLR is not a simple winwin solution on unoccupied, degraded lands that otherwise would remain unused. Further, land once restored creates new assets, whetting appetites of different actors to acquire or use those assets (Mansourian 2016). For the sake of longterm ecological, economic, and social benefits for many people, FLR inevitably has to deal with conflicts of interest and seeks fair ways to designate losers and minimize resistance. Conflicting interests may be dealt with by fully considering legitimate claims to resources in landscapes through economic incentives, education, or capacity building and especially through transparent implementation (Mansourian 2017; Stanturf et al. 2017).

\subsection{Time needed}

Restoration requires time for interventions to result in positive change toward defined objectives. The original conception of the Bonn Challenge was 150 million ha of degraded landscape would "be restored" by 2020 . Realizing the impossibility of measuring significant positive change in such a short time, the wording was changed to "under restoration." In addition to the time needed for ecosystems to recover, social processes require time for developing trust among participants (Khadka and Schmidt-Vogt 2008; Metcalf et al. 2015). Partnerships and strong working relations among communities, local and regional governmental organizations, NGOs, and donor organizations are necessary for helping communities to enforce forest use and management rules, provide financial and technical support for restoration and conservation activities, and increase community capacity to sustainably and equitably manage forests and other natural resources (Charnley 2017; Gutierrez-Montes et al. 2009; Gutiérrez-Montes 2017).

The disparity in time scales, between the urgency of restoring degraded land and the longer time needed to address governance issues (Mansourian 2017) and attain positive ecological and livelihood changes, underscores the need for long-term commitment to FLR. Ghana, for example, has committed to restoring 2 million ha of deforested and degraded landscapes by 2030 under the Bonn Challenge and the AFR 100 (http://afr100.org/content/ghana; Foli 2017). Although supportive policy and regulatory frameworks exist, reforms are still required to harmonize customary and statutory laws. Land access and secure tree tenure remain critical elements for policy makers to address (Blay et al. 2008; Damnyag et al. 2012). Successful restoration in Ghana will depend on participatory forest management and monitoring, as well as effective enforcement of forest legislation related to land and tree tenure (Hansen 2011; Wardell and Lund 2006).

\section{Applying project cycle management to FLR}

Into the constantly evolving socioeconomic, political, and natural environments described above, project cycle management (PCM) is a systematic framework (Fig. 2) that can be useful for designing, planning, steering, and 
monitoring an FLR project or initiative (Battisti 2017). The PCM framework is not a simple, linear process but rather is iterative, adaptive, and hierarchical with recurring consultations among stakeholders (Stanturf et al. 2017). The implementation process operates at multiple spatial and temporal scales, and there are many useful planning tools available that may be adapted to FLR (e.g., Kusters et al. 2017; Tobón et al. 2017). Welldefined goals and reconciled objectives are indispensable for success. This can only come about from a clear process of engaging local stakeholders (Buckingham et al. 2018; Mansourian and Parrotta 2018). Expectations of the shared vision of the restored landscape must be stated in terms of objectives that can be implemented with an explicit understanding of the mechanisms and trajectory that connects them to the desired endpoint (Hobbs 2007; Hughes et al. 2005).

In FLR, PCM has four phases that progress toward greater specificity with flexible timing (Table 1 ). Feedback at regular intervals in the cycle allows for opportunities to shuffle priorities, shift implementation activities, and re-align resources in light of changing conditions and new information by continuous learning coupled with adapting to increased knowledge.

Visioning sets out the aspirational goals for FLR, often at a national or regional level, but casting a vision, and getting buy-in, is needed locally as well (Stanturf et al. 2017). Goals may acknowledge international commitments such as biodiversity targets; monitoring, assessments, and research on degradation and/or deforestation drivers may inform the visioning phase by identifying opportunities and obstacles. Conceptualizing turns goals into clear and measurable objectives that can be acted upon. This phase determines the most feasible and effective interventions for the target landscape that may be derived from national, regional, or local goals. During the conceptualizing phase, selecting priority regions or landscapes to focus activities may gain the most benefit from limited resources. The acting phase plans activities to turn objectives into accomplishments by developing a sequenced list of what will be done, where, when, by whom, and at what cost (Stanturf et al. 2017). Sustaining FLR over the long term combines management planning with monitoring and evaluation in order to provide feedback into earlier phases for potential corrective actions. Some examples will illustrate the four phases and the hierarchical nature of PCM, with the greatest emphasis on the conceptualizing and acting phases.

\subsection{Visioning}

Visioning sets the goals for what comprises a restored environment and the ecological and social benefits flowing from a well-functioning landscape. Often these goals will be identified by what is presently lacking, degraded, or both and should

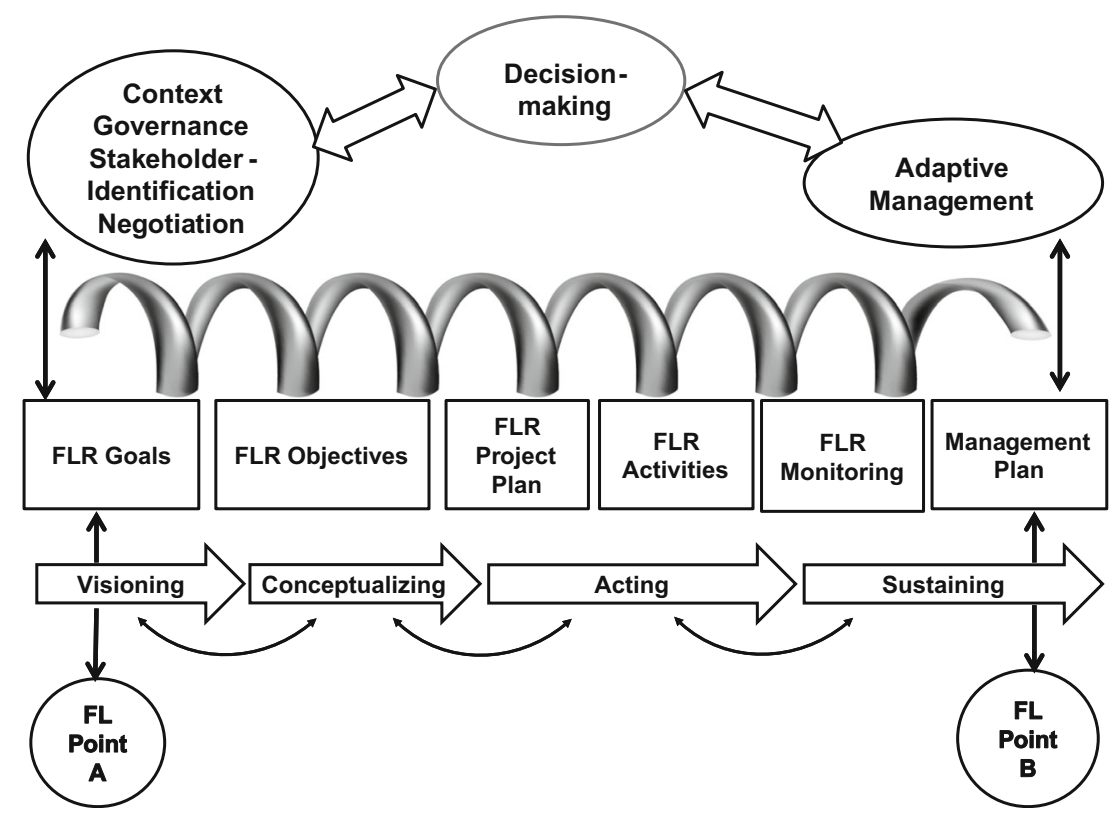

Fig. 2 Project cycle management (PCM) applied to forest landscape restoration (FLR) has four phases: visioning, conceptualizing, acting, and sustaining. PCM is an adaptive, iterative process for moving from broad goals (a vision) for improving the current condition of the forested landscape (FL point A) by conceptualizing tangible, measurable objectives that can be acted upon, resulting in a future restored conditions (FL point B). To ensure the sustainability of FLR, monitoring and long-term management must be integrated into the FLR project and feedback into decision-making (adaptive management). Ample opportunities exist at all phases for feedback and iteration of previous negotiations as new conditions, knowledge, or stakeholders emerge. Preceding PCM initiation and negotiation of goals, environmental and social contexts are recognized (including governance and stakeholder identification) 
Table 1 Hierarchical nature of project cycle management illustrated with an example from Rwanda (MINIRENA 2014)

\begin{tabular}{|c|c|c|c|c|}
\hline Phase & Visioning & Conceptualizing & Acting & Sustaining \\
\hline Realization & Goal & Objective & Plan & Feedback \\
\hline Meaning & $\begin{array}{l}\text { The purpose } \\
\text { toward which an } \\
\text { FLR project is } \\
\text { directed }\end{array}$ & $\begin{array}{l}\text { Accomplishments or } \\
\text { targets of one's } \\
\text { efforts or actions }\end{array}$ & $\begin{array}{l}\text { Activities that will } \\
\text { result in } \\
\text { accomplishments or } \\
\text { meet targets }\end{array}$ & $\begin{array}{l}\text { Adaptive } \\
\text { management }\end{array}$ \\
\hline Measure & $\begin{array}{l}\text { Goals may or may } \\
\text { not be strictly } \\
\text { measurable or } \\
\text { tangible }\end{array}$ & $\begin{array}{l}\text { Must be measurable } \\
\text { and tangible }\end{array}$ & $\begin{array}{l}\text { Sequenced list of what } \\
\text { will be done, where, } \\
\text { when, by whom, at } \\
\text { what cost }\end{array}$ & $\begin{array}{l}\text { Monitoring, } \\
\text { Management Plan }\end{array}$ \\
\hline $\begin{array}{l}\text { Time } \\
\text { frame }\end{array}$ & Long-term & Mid- to short-term & Mid- to short-term & Long-term \\
\hline Example & 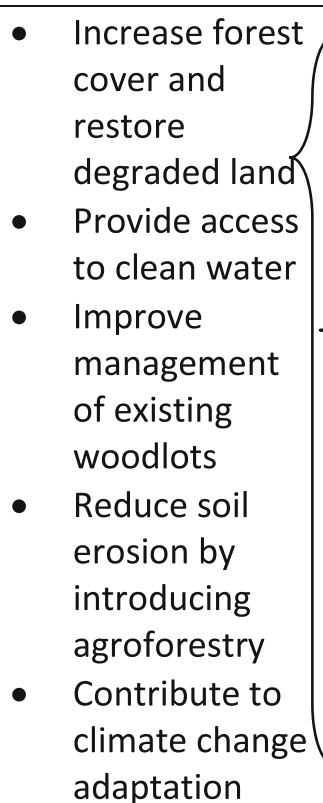 & $\begin{array}{l}\text { Protect and restore } \\
\text { natural forests } \\
3000 \text { ha new } \\
\text { forests } \\
20,000 \text { ha } \\
\text { Eucalyptus } \\
\text { replaced } \\
100 \text { m buffers } \\
\text { natural forests } \\
\text { planted around } \\
\text { natural areas } \\
\text { Restore } \\
\text { degraded areas } \\
\text { within reserves } \\
\text { and parks }\end{array}$ & $\begin{array}{l}\text { Plant } 100 \text { ha native } \\
\text { species in } 20 \text { m buffers } \\
\text { along rivers in Kigali } \\
\text { Province in October by } \\
\text { local farmers }\end{array}$ & $\begin{array}{l}\text { Monitor } \\
\text { development } \\
\text { Planned } \\
\text { interventions } \\
\text { - Course } \\
\text { corrections } \\
\text { - Maintenance }\end{array}$ \\
\hline
\end{tabular}

The goal of increasing forest cover and restoring degraded land is realized by the objective of restoring natural forests. One action to implement the objective is to plant riparian buffers of native species in Kigali Province. This also meets the goal of providing access to clean water by protecting the river bank

emanate from multi-stakeholder consultations. A simple exercise can be useful to define goals and structure negotiations on objectives. Two questions (Do we have it? Do we want it?) lead to four possible categories of objectives for preserving or eliminating current conditions or achieving or avoiding certain future conditions (Fig. 3). The "it" may be an ecosystem service (e.g., protection from flooding), an ecological benefit (e.g., protecting endangered species), or an economic benefit (e.g., sustainable fuelwood).

Goals generally describe expected long-term outcomes and may or may not be strictly measurable or tangible, depending upon the scope and level of consideration (Stanturf et al. 2017). Understanding what is needed can be gained through national surveillance monitoring (Hutto and Belote 2013; Petrokofsky et al. 2011), socio-ecosystem assessments (De
Vreese et al. 2016; Halofsky et al. 2014), and establishing baselines of current conditions of important functions (Table 2) that feed into stakeholder engagement processes.

Goals may be defined in a landscape hierarchy. For example, FLR in El Salvador is largely a top-down process, using the Restoration Opportunities Assessment Methodology (ROAM) (MARN 2017) to develop goals and objectives. Participatory analysis of landscape degradation identified concerns for surface and groundwater, adaptation to drought, soil conservation and agriculture, floods and storms, biodiversity, climate regulation by urban cities, and rural communities need for firewood. Further participatory processes will define objectives, prioritize the sites to restore, and identify restoration techniques to use. In order to monitor and measure the impact of restoration interventions in the medium and long terms, an 
Examples from Rwanda

\begin{tabular}{|c|c|c|c|c|c|}
\hline \multirow{3}{*}{$\begin{array}{l}\text { Do we } \\
\text { have it? }\end{array}$} & No & Achieve & Avoid & \multirow{2}{*}{$\begin{array}{l}\text { Achieve (establish) } \\
\text { protective forests on } 50 \% \\
\text { of ridgetops and slopes } \\
\text { greater than } 55 \%\end{array}$} & \multirow[t]{2}{*}{$\begin{array}{l}\text { Avoid exotic plantations } \\
\text { in buffer areas around } \\
\text { protected areas }\end{array}$} \\
\hline & Yes & Preserve & Eliminate & & \\
\hline & \multicolumn{3}{|c|}{$\begin{array}{l}\text { Yes No } \\
\text { Do we want it? }\end{array}$} & $\begin{array}{l}\text { Preserve corridors } \\
\text { between protected areas }\end{array}$ & $\begin{array}{l}\text { Eliminate row crops on } \\
\text { lands with } 20-55 \% \text { slope }\end{array}$ \\
\hline
\end{tabular}

Fig. 3 A schematic for developing objectives and guiding discussion poses two questions: Do we have it? Do we want it? (It can refer to environmental or social condition). Answering these two questions leads to four possible objectives of preserving or eliminating current conditions or achieving or avoiding certain future conditions. This approach applied to Rwanda is illustrated by four objectives inter-institutional, interdisciplinary national monitoring plan is being defined (MARN 2017). Local restoration and monitoring plans will be developed that need to be implemented by alliances of municipalities, farmer associations, and government agencies.

Identifying goals does not have to be a top-down exercise. In many countries, there is a host of small projects scattered across the landscape. Chile, for example, has committed to restore approximately 500,000 ha by 2030 . Since 1990 , many small restoration initiatives have been reported but most are isolated examples (<1 ha) (Vargas 2017). Scaling-up technical knowledge from research studies to operational activity at the landscape scale, however, can be difficult (e.g., Stanturf et al. 2001). Nevertheless, the experience of the Atlantic Forest Restoration Pact shows how over 270 public and private organizations came together to organize small restoration projects into a national movement (Brancalion et al. 2013; Giorgi et al. 2014).

\subsection{Conceptualizing}

Conceptualizing requires setting tangible and measurable objectives or targets that accomplish the restoration goals and describe the desired future condition of the landscape (Table 1) or units within the landscape (Table 2). The relationship of goals to objectives can be seen in an example from Rwanda (Table 1). The goal of increasing forest cover was linked to the objective of protecting and restoring natural forests, which has five specific sub-objectives. Creating productive, resilient landscapes typically will involve selecting approaches that are feasible and effective in the specific ecological and social context from a variety of possible restoration (Chazdon 2015; Dumroese et al. 2015) and livelihood approaches (Angelsen et al. 2014; Garibaldi et al. 2017).

\subsubsection{Social approaches}

Meeting the ambitious targets of the Bonn Challenge requires selecting from approaches that provide economic incentives, enabling regulations, or targeted education that modify or replace existing land use systems. Mobilizing and using available scientific, local, and traditional knowledge and technical expertise is critical for achieving successful FLR (Rerkasem et al. 2009; Uprety et al. 2012). While FLR emphasizes participation of local communities, often local people lack the capacity or resources to be fully engaged. Community members need tangible, meaningful, and sustained incentives to support restoration activities so that the benefits of conservation and restoration outweigh the costs. Key challenges are identifying and sustaining appropriate incentive mechanisms that are linked to conservation and equitably distributing the costs and benefits among community members (e.g., Charnley 2017).

\subsubsection{Adaptive capacity}

Developing adaptive capacity locally can greatly facilitate FLR processes and improve outcomes (Gutiérrez-Montes 2017). Increasing income (nursery work, planting, monitoring), providing alternative livelihoods (non-timber forest products or ecotourism), or improving agricultural yields through sustainable intensification (Rockström et al. 2017) all contribute to local adaptive capacity and buffers against short-term economic or political costs. In densely populated India, for example, linking restoration to employment generation makes it socially relevant and politically attractive (Kant and Burns 2017). The sustainable livelihood approach used in Latin America sees livelihoods as encompassing the full range of resources and assets needed for families to live, as well as community capital and capacities (Gutierrez-Montes et al. 2009).

\subsubsection{Economic drivers}

A variety of economic drivers can be used to improve overall landscape functioning including timber and fuelwood production, new markets, and payments for ecosystem services such as carbon, water quantity, and quality (Harper et al. 2012; 


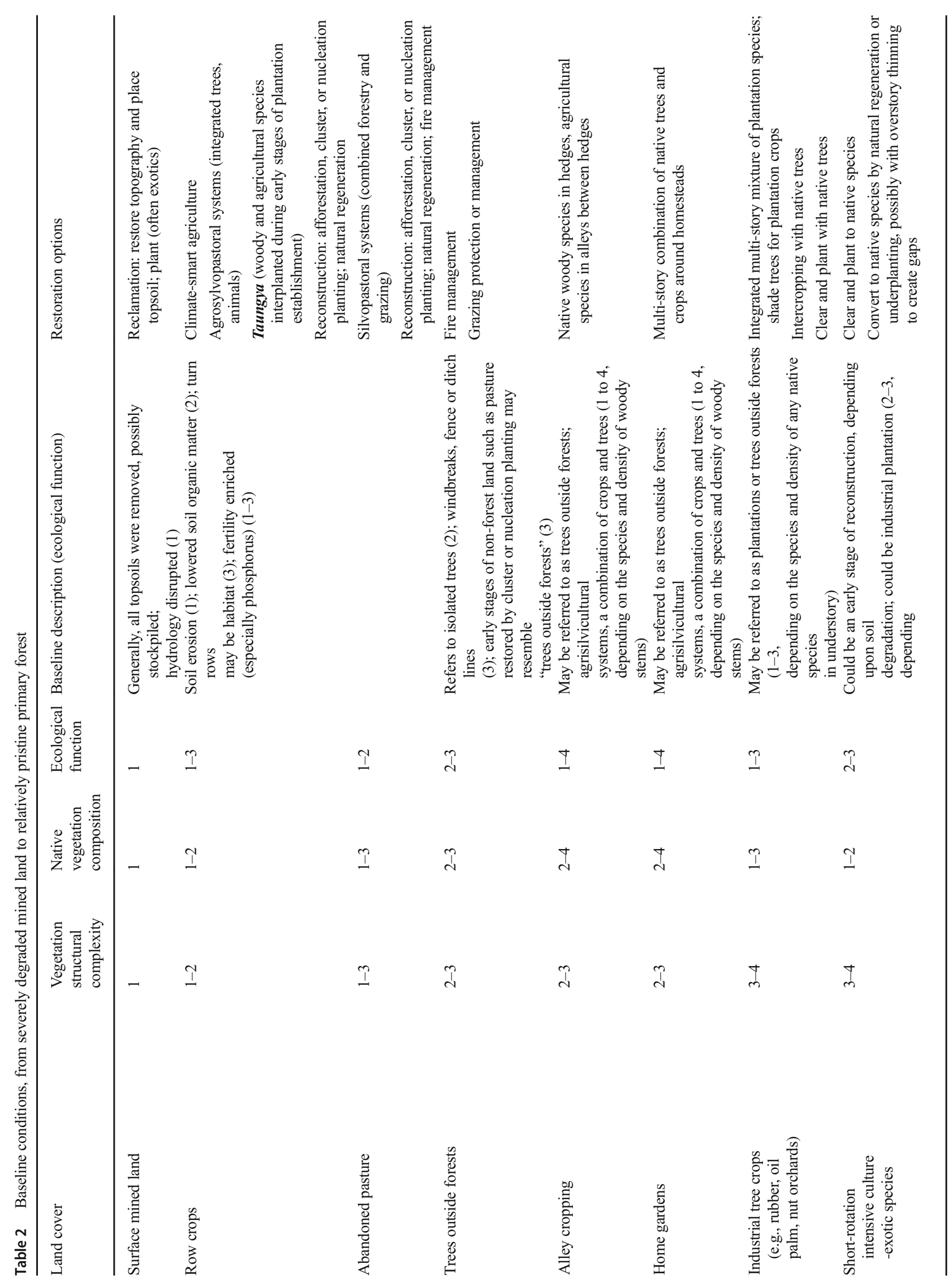




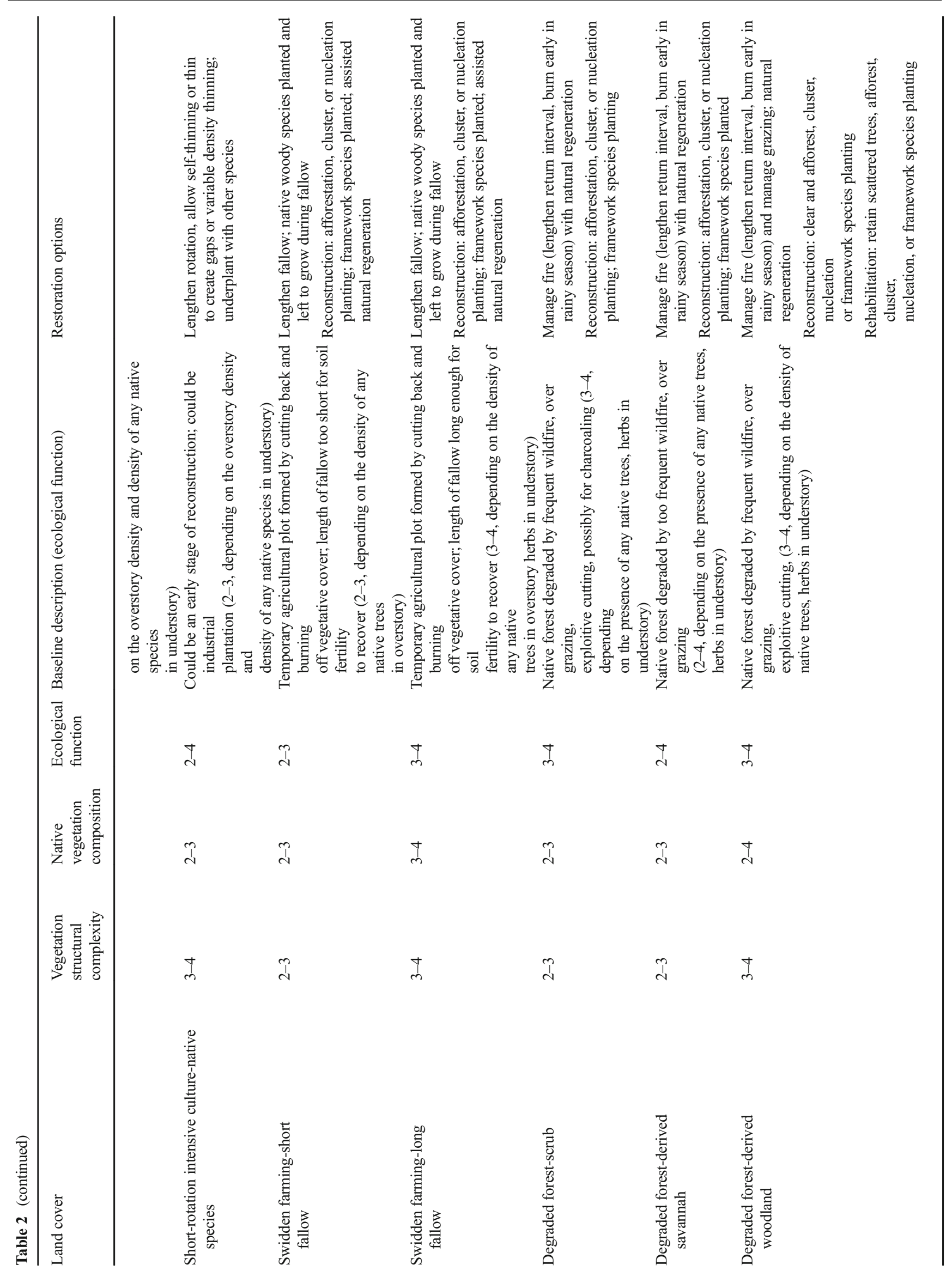




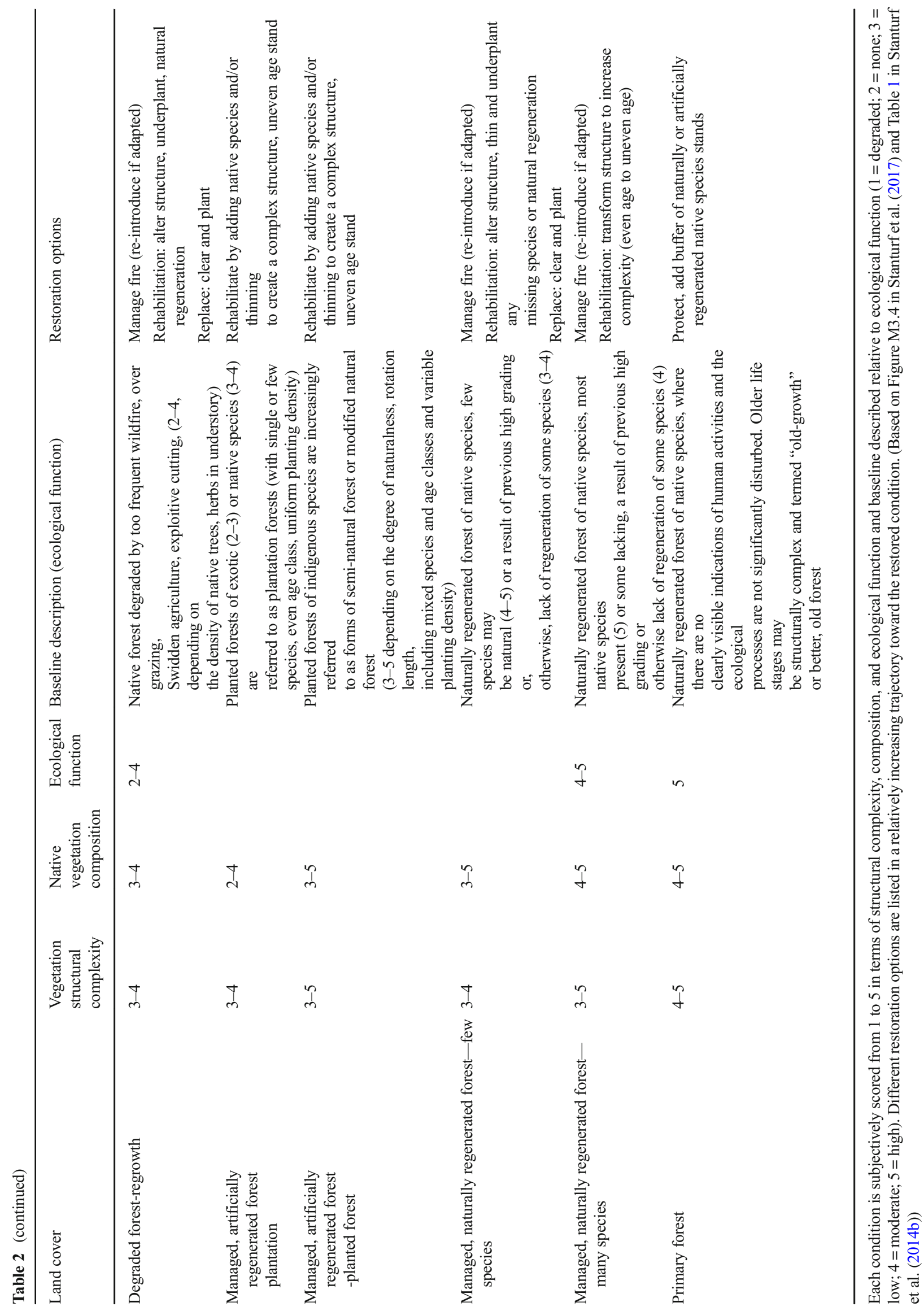


Wunder et al. 2008). Integrating FLR principles and improved environmental standards into the entire value chain for goods and services can contribute to long-term FLR success. For example in Central Kalimantan (Indonesia), green rural development and financial incentives created through timber production or agroforestry are achieved using fast-growing native species (Anthocephalus spp. and Azadirachta excelsa) and developing markets for innovative products (Schwegler 2017). Market analyses and product innovation for fastgrowing timber species have proven crucial to safeguard high returns over a relatively short time.

Using co-benefits (e.g., carbon, water, ecosystem services) to drive change has been widely touted, but in many cases, payments for co-benefits have not been materialized (Evans 2018; Osborne and Shapiro-Garza 2018). Even in Costa Rica, which has a long history with payments for ecosystem services (Pagiola 2008), Louman (2017) found that both incentives (payment for environmental services) and regulations (land use change prohibition) were insufficient motives for FLR in rural areas and needed to be accompanied by promoting the value of forests and trees, providing technical assistance, and empowering local leadership.

\subsubsection{Environmental context}

Restoration objectives may be easiest to define but hardest to achieve where severe degradation has occurred, for example mined land or severely eroded agricultural land. Severely degraded sites are difficult to restore because the topsoil has been removed or contaminated, resulting in physical or chemical barriers to plant establishment (Stanturf et al. 2014a). Opencast or surface mining, from large industrial operations to smaller artisanal mining, affects a relatively small area globally but has considerable impact locally and regionally. Reclamation of these areas using forest plantations can restore productivity, biological diversity, and ecological functioning (Macdonald et al. 2015; Parrotta and Knowles 2001). Because of harsh site conditions and loss of ecosystem memory, initially non-native species often are used (Lamb et al. 2005; Parrotta et al. 1997). Severely degraded sites may develop along varied trajectories, depending upon soil depth; over time, native species may establish under the non-native overstory as site improves (Parrotta et al. 1997). The non-native overstory accelerates restoration by moderating understory temperature, humidity, and light, resulting in improved conditions for natural regeneration and suppression of competing grasses or ferns. In Estonia, for example, novel site conditions on reclaimed oil shale mines allowed threatened herbaceous species to colonize spontaneously (Laarmann et al. 2015). This catalyst effect can also be accomplished with fastgrowing native species under less-degraded conditions (Stanturf et al. 2014a).
Drylands are somewhat less degraded than mined land, but water-limited dryland forests often prove more difficult to restore than tropical or moist temperate forests. Globally, some $10-20 \%$ of drylands are degraded (Hassan et al. 2005) and severe problems arising in drylands include soil salinization. In south-western Australia, deforestation of native Eucalyptus forests and conversion to agriculture caused a hydrologic imbalance, salinizing approximately 10,000-20,000 $\mathrm{km}^{2}$, compromising water sources, and placing more than 500 species at risk (Harper et al. 2017). Rather than simply abandoning the salinized land, economically attractive alternatives included innovative systems of agroforestry strips of short-stature Eucalypts (mallees), biodiversity plantings of multiple native species, species adapted to saline soils (e.g., Eucalyptus and Atriplex), tax deductions for forestry investment, carbon markets, and bioenergy (Harper et al. 2012; Harper et al. 2014).

The Aral Sea region in Central Asia provides another example of attempting to reverse dryland degradation (Mirzabaev et al. 2016). Two problems exist: water extracted for irrigation exposed sediments of the shrinking Aral Sea to severe erosion (Micklin 2010) and agricultural abandonment after irrigation developed a shallow saline groundwater table. Solutions included planting saxaul (Haloxylon spp.) on the exposed sediments (Botman 2009) and conversion of marginal agricultural land to tree plantations before critical levels of salinization develop (Botman 2009; Worbes et al. 2006). These efforts are part of recent Bonn Challenge commitments (http://www.fao.org/europe/news/detail-news/en/c/ $1142410 /)$.

\subsubsection{Landscape structure}

Mosaic landscapes provide the greatest opportunity for FLR (Minnemeyer et al. 2011). These are landscapes with moderate human occupancy and generally combine forests or woodlands with agriculture and small settlements, typical of many rural landscapes globally. In mosaic landscapes, there are four paths for already degraded and deforested land: restore to (1) productive agriculture; (2) mixed agroforestry with woody perennials integrated into crop and livestock systems; (3) actively managed, productive forests; or (4) passively managed, protected forests. In Ethiopia, the approach to building productive landscapes and avoiding deforestation has focused on intensifying agricultural production through introduction of high-yielding crops and improved livestock and by improving management of productive forests. Free grazing by large livestock herds remains to be the main challenge to FLR efforts in Ethiopia, and efforts at restricting grazing (e.g., by exclosures) are considered part of its FLR commitment (HermansNeumann et al. 2017; Pistorius et al. 2017).

Agroforestry and trees outside forests in mosaic agricultural landscapes can be among the major tools to achieve large- 
scale restoration. Indeed, ROAM assessments for the Bonn Challenge commitments in Rwanda and Uganda highlight agroforestry potential (MINIRENA 2014; Ministry Water and Environment 2016). Farmers, livestock, trees, and forests interact at multiple scales, influenced by customary tenure and regulations. Many countries committed to the Bonn Challenge are undergoing significant political and cultural transitions that likely will constrain how FLR is implemented. Kyrgyzstan, for example, is an economy in transition, and land use rules and laws are relicts of a centrally planned economy that specified what crops could be planted. Rules regarding agroforestry are unclear, presenting a major obstacle to innovation. Nevertheless, Populus spp. (poplars) have been planted by the private sector partly in $250 \mathrm{~m} \times 250 \mathrm{~m}$ gridded windbreaks. Extending these linear plantings to all the croplands of Kyrgyzstan would meet the local demand for timber and fuelwood in a country with limited forest resources (Razhapbaev 2017; Thevs and Aliev 2017).

Combining production with conservation objectives can provide biodiversity and multiple ecosystem services (Brockerhoff et al. 2008; Silva et al. 2018). At the landscape level, intermixing sustainably managed production and restored native forests provides landscape diversity (Payn et al. 2015). Planted forest options differ in their potential to deliver benefits to people as well as their potential biodiversity impacts. Depending on restoration goals and objectives, planted forests may include agroforestry to meet food and nutritional security; short- or long-rotation plantations or mixed-species plantings for timber, fuelwood, and livelihood diversification; or silvicultural treatments to restore species and structure to native forests (Keenleyside et al. 2012; Stanturf et al. 2014a).

\subsection{Acting}

The objective of forest restoration is to change vegetation composition, structure, or both (Meli et al. 2017; Stanturf et al. 2014a) through passive or active means, or some combination of the two. Restoration interventions take place locally, and the combination of these local actions affects the landscape. Restoration decision-making at local levels is comprised of site selection; choice of FLR activities; the pace and the schedule of implementation, costs, and monitoring of work linked to expenditures; and evaluation for feedback to address shortcomings (Stanturf et al. 2017). Before commencing actual implementation activities, several factors should be in place. Stakeholders who will set goals and participate in the project should have already been identified and engaged. Nationally, the regions or landscapes targeted for restoration should have been identified and appropriate collaboration and consultations begun with affected local communities (Stanturf et al. 2017). Importantly, tenure relationships in the project area must be understood and considered in objectives, but not necessarily resolved. Identifying appropriate solutions can be impaired by power relations (Raik et al. 2008). Further, governance challenges exist in such interventions as FLR and need to be acknowledged and addressed in a culturally, socially, and politically sensitive manner (Mansourian 2016). Plans must be acceptable to local stakeholders. By including in the plans specific longer-term land use objectives (what should be produced, how, for whom), FLR can be seen as a pathway to reach these specific objectives. Meeting local needs may require compromises with the national approach on some issues, but compromises should not encourage corruption, or gender and other kinds of discrimination (Kolstad and Søreide 2009; Reinecke and Blum 2018).

The hierarchical nature of project planning is illustrated in Table 1 for Rwanda (MINIRENA 2014). The five goals are similar to those for El Salvador (MARN 2017). Taking one of the goals, "Increase forest cover and restore degraded land," several objectives were developed that included protecting and restoring natural forests, to be accomplished by planting 3000 ha of new forests, replacing 20,000 ha of Eucalyptus plantations with native species, planting $100 \mathrm{~m}$ forest buffers around natural areas, and restoring degraded areas within reserves and parks. For each of these activities, a plan will address the specific questions listed above; the example given is to plant 100 ha of native species in buffers $20 \mathrm{~m}$ wide along rivers in Kigali Province. Planting would be done early in the rainy season by local farmers. Note that this activity also contributes to the goal of providing access to clean water.

\subsubsection{Site selection}

Because of spatial heterogeneity in physical and ecological characteristics, disaggregating the target landscape into more or less homogeneous units that are expected to respond similarly to important constraints and stressors improves the chances for successful interventions. This can be done efficiently by overlying GIS layers of topographic characteristics, soil, geology, vegetation, climate parameters, and land use. Participatory mapping by local stakeholders can add important social dimensions (Evans et al. 2018; Sacande and Berrahmouni 2016). Rules for combining and weighting layers may rely on expert local knowledge and objectives and are sensitive to the scale being considered (GarcíaQuijano et al. 2008). This step recognizes that the diversity and complexity of landscapes is essential for national- or regional-level FLR and is useful at localized levels where diverse topography, varied community ethnicities, or both make for different priorities or acceptability of some activities.

\subsubsection{Restoration strategy}

Passive restoration requires ready dispersal and recolonization from nearby sources or in situ regeneration arising from a seed 
bank or sprouting (Chazdon 2015; Holger et al. 2015). Excessive browsing by wild or domestic animals may preferentially remove desirable species and establish a long-lasting barrier to regeneration (e.g., Kain et al. 2011; Rooney et al. 2015) and requires protection such as fencing to exclude animals. Active restoration by direct seeding or outplanting of desirable species provides many options for covering part or all of an area (Cole et al. 2011; Engel and Parrotta 2001). Assisted natural regeneration, combining active and passive methods, usually involves clearing weeds to reduce competition on desired seedlings or sprouts (Elliott 2016). The extent of soil and vegetation degradation determines whether the starting point is characterized by physical or biological limitations that must be overcome, for example by site preparation such as bedding or mounding (Stanturf et al. 2014a). Good quality seedlings are critical for success for all planting techniques and all restoration objectives (Dumroese et al. 2016). Especially critical in the early stages of restoration development are silvicultural and management practices, including protection from fire and other disturbances. At later stages, further interventions may be needed to increase biodiversity such as thinning to open gaps for additional species to establish (Stanturf et al. 2017).

Silvicultural and management decisions for all types of planted forests can yield "win-win" outcomes for biodiversity conservation and restoration, provision of ecosystem services, and direct livelihood benefits to people (Brockerhoff et al. 2008; Sacande and Berrahmouni 2016). The likely impacts of planted forests on biodiversity depend on what they are replacing - context is critical. Several factors operating at the landscape level mediate the biodiversity impacts of planted forests including land use history and its impact on soils, vegetation, and wildlife. These legacies of previous land use may set the restoration trajectory (Jõgiste et al. 2017; Johnstone et al. 2016). Restoration may also involve removing unwanted vegetation such as invasive exotic grasses or herbaceous plants (Stanturf et al. 2014a), for example Pteridium spp., Lantana camara, or Imperata cylindrica.

Planting trees on degraded sites (Table 3) that are unlikely in the near term to recover through natural regeneration can accelerate restoration (Palma and Laurance 2015; Saha et al. 2016). Several factors affect the rate and extent of biodiversity recovery in planted forests, mainly the context, starting point, and management (Stanturf et al. 2014a). Context refers narrowly to the biological diversity in the surrounding landscape matrix including the proximity to forest remnants for seed sources and dispersal agents (Emer et al. 2018; Wunderle Jr 1997). Broader aspects of context refer to exogenous factors that might affect the sustainability of restoration such as likelihood of land use change driven by changes in government policies or markets. Brazil's Atlantic Forest Restoration Pact recognized the broader context and the potential need of land for agriculture and infrastructure so they concentrated their efforts on marginal land remote from urban centers (Melo et al. 2013).

High-grading and other exploitive uses that remove large trees of commercially valuable species without ensuring adequate regeneration can be corrected by planting the missing species under an existing overstory that may be retained or removed (Dey et al. 2012; Gardiner and Yeiser 2006). Underplanting native species in non-native plantations is a way to convert these plantations to mixed forest (Iwasa et al. 1994; Parker et al. 2001). Underplanting may be preceded by site preparation such as soil scarification with heavy machinery to mimic large-scale and intensive disturbance (Soto et al. 2015). For example, in the Andes Mountains of South America, Nothofagus dombeyi and Nothofagus alpina have a high survival rate and good (but highly variable) growth when planted under high-graded forests following understory control (Donoso et al. 2015; Donoso et al. 2013). They facilitate natural regeneration, greater diversity, and forest succession.

\subsubsection{Species selection}

The challenge of restoring resilient, diverse forest landscapes faces a major obstacle of obtaining quality seedlings, beginning with obtaining quality seed (Jalonen et al. 2017; Nyoka et al. 2015). Selecting which species to plant, by what method, and in what density and pattern are decisions based on objectives, the likelihood of successful establishment on the sites available, and the availability of good quality seedlings in the number needed at an affordable cost (Stanturf et al. 2014a). Objectives play a critical role in the choice of species; desirable traits (growth rates, tree form, fruit or nut production, fodder, utility for wildlife, soil improvement potential) dictate the candidate species (Sacande and Berrahmouni 2016). In any case, procuring quality nursery stock is a critical first step (Dumroese et al. 2016; Haase and Davis 2017) and the only opportunity to directly influence the genetics available for climate change adaptation (Doherty et al. 2017; Thomas et al. 2014). High-quality stock, planted correctly at the proper time, maximizes survival and accelerates the forest restoration trajectory (Dumroese et al. 2016; Stanturf et al. 2014a).

Selecting the correct species to plant is not straightforward in former agricultural landscapes lacking examples of relatively undisturbed native forests. Even when forest remnants are available to guide species selection, the remnants may not be representative of the sites to be planted. Proper context involves matching to sites at the species and genetic levels with selections appropriate to today's climate as well as future conditions (Jump and Penuelas 2005; Keenan 2015). Understanding the distribution of natural vegetation provides a good approximation of where wider planting of native tree species will contribute to ecosystem services, and food and nutrition security. For example, the vegetationmap4africa (http://www.vegetationmap4africa.org/ Home.html) is an interactive vegetation map designed as a 
Table 3 Forest restoration designs, from simple to complex, based on the number of species and cohorts and spacing (terminology from Stanturf et al. 2014a, 2014b)

\begin{tabular}{|c|c|c|c|c|}
\hline Number of species & Number of cohorts & Spacing & Variations & Options \\
\hline \multirow[t]{4}{*}{ Single } & \multirow[t]{4}{*}{ Single } & \multirow[t]{2}{*}{ Dispersed } & Cluster planting & Later infilling by natural regeneration \\
\hline & & & Applied nucleation & Later infilling by natural regeneration \\
\hline & & \multirow[t]{2}{*}{ Uniform } & Planted into cover crops & $\begin{array}{l}\text { Original stand thinned or removed and planted } \\
\text { with other species }\end{array}$ \\
\hline & & & Taungya & $\begin{array}{l}\text { Trees interplanted with agricultural crops until } \\
\text { canopy closure }\end{array}$ \\
\hline \multirow[t]{9}{*}{ Multiple } & \multirow[t]{5}{*}{ Single } & \multirow[t]{2}{*}{ Uniform } & Temporary mixture & Interplanting or nurse crop that is removed early \\
\hline & & & Permanent, simple mixture & Single-species rows or blocks \\
\hline & & Random & Permanent, intimate mixture & High-density planting, framework species \\
\hline & & Uniform & Permanent, intimate mixture & Designed mixture \\
\hline & & Dispersed & Framework species planting & Complemented by natural regeneration \\
\hline & \multirow[t]{4}{*}{ Multiple } & \multirow[t]{2}{*}{ Dispersed } & Permanent, intimate mixture & $\begin{array}{l}\text { Cluster with multiple species and natural regeneration } \\
\text { between clusters }\end{array}$ \\
\hline & & & Permanent, intimate mixture & Nucleation and natural regeneration to fill-in open spaces \\
\hline & & Uniform or random & Underplanting & With or without partial overstory removal \\
\hline & & Random & Release advance regeneration & With or without partial overstory removal \\
\hline
\end{tabular}

decision support tool for the selection of suitable indigenous tree species for restoration, forestry, agroforestry, and landscape diversification projects. The map also shows where to obtain planting materials for a particular species (Lillesø et al. 2011).

\subsection{Sustaining}

Restoration is a long-term process that likely will extend far beyond the initial interest and influx of funding. Maintaining momentum and sustaining interest over the time needed to show results require adaptive management that includes monitoring and effective feedback to make necessary corrections or to undertake needed further interventions such as thinning. The world around the restoring landscape will be changing as well, driven by climate change, globalization, land use, and policy shifts. Effective monitoring is a key to sustaining FLR (Hutto and Belote 2013; Stanturf et al. 2017). To be successful, monitoring should be responsive to key management questions based on criteria of successful restoration. An international effort to identify generic FLR indicators led by FAO (Zoveda 2017) may complement more technical approaches such as carbon monitoring (e.g., Petrokofsky et al. 2011). A critical issue is how intensively to monitor (e.g., Viani et al. 2018) and whether the needed resources are available. In addition to monitoring the restoration project, attention to the external drivers should be included in the overall monitoring system by incorporating data provided by government agencies and NGOs (e.g., Platteau 2004; Vittek et al. 2014).

Participatory monitoring offers local communities opportunities for meaningful participation in FLR (Brancalion et al.
2013; Evans et al. 2018). Collaboratively selecting indicators and local drivers of success to monitor and using locally appropriate technologies to collect data adequate for decisionmaking can create ownership, get buy-in, and develop trust (Evans et al. 2018; Kusters et al. 2017). Such a system involving women and marginalized groups may increase speed and effectiveness of local decision-making and catalyze social learning. Local monitoring can be cost-effective and reliable, but it requires investment in appropriate training, motivation, and quality control (Evans et al. 2018). Participatory monitoring as a multi-scale, multi-site system may necessitate a dedicated, centralized, possibly government-led platform, but care must be taken to balance national versus local needs and goals (Brancalion et al. 2013; Evans et al. 2018).

\section{Future needs}

The historic examples of Denmark, South Korea, and Puerto Rico showed that restoration has been successful without today's political enthusiasm, access to funding, and practices supported by broad science-based evidence. Our predecessors managed by simple shared visions to restore forest cover in degraded and previously forested landscapes. Their vision was shared across their society and aided by supportive policies. Only by successfully implementing FLR will we validate the Bonn Challenge and overcome the enthusiasm gap (Fig. 1). Nevertheless, focusing only on success can obscure critical factors unique to social context and historic period. We need to devote more attention to failures, to learning when and why 
techniques did not work or meet objectives. In addition to analyzing failed attempts, we need to share the results broadly through learning networks, communities of practice, and knowledge platforms.

The complexity of landscapes as socio-ecological systems can be a strength instead of a problem for FLR if approached as incorporating a portfolio of diverse objectives and methods. Trying different objectives and methods may spread the risk of failure across landscapes and stakeholders. Acceptance and even encouragement to attempt and evaluate different methods to address common visions will allow individual entrepreneurship and curiosity. Application of different solutions may strengthen adaptation to the uncertainties of future environmental conditions, markets, and population pressures on restored landscapes. Importantly, will future landscapes become depopulated due to outmigration to cities or will an upcoming bioeconomy and the restored landscapes make them more attractive for settlement? Attractive solutions for the present generation may not be the same for future generations.

Social adaptation to global change generally, and with regard to FLR, will be challenging (Stanturf 2015). Future work on FLR should concentrate on three areas: improving governance related to land tenure and use (Holden et al. 2013; Mansourian 2016), developing capacity (Brooks et al. 2005; Smit and Wandel 2006), and gaining the knowledge needed to address climate change challenges (Gellie et al. 2018; Puettmann 2014). Many countries such as Ghana have made progress in forest governance, spurred by the need to become "REDD Ready" (Hansen et al. 2009; Murdiyarso et al. 2012). Capacity building at different levels is important, but a general need is to develop a cadre of landscape generalists who understand adaptive management and who can work in interdisciplinary and multi-cultural settings. These individuals should value tangible and intangible landscape values, such as economic and ecological benefits and cultural significance. They should be adept at integrating policies and practices and be open to new knowledge, skills, and attitudes. These landscape generalists would facilitate FLR implementation, bringing together technical knowledge with sensitivity to local conditions and stakeholder objectives. Their ranks could be drawn from government agencies, local universities, NGOs, and local communities.

Many native forest tree species already have been extirpated or are severely threatened by introduced pests and pathogens. Re-introduction of threatened tree species offers FLR an opportunity to help meet the targets of the Bonn Challenge and associated policy initiatives, while simultaneously restoring keystone forest species (e.g., Jacobs et al. 2013). Societal and ecological barriers to FLR using non-native species remain but are evolving (Breed et al. 2018; Bucharova et al. 2017); however, resistance to genetically modified organisms remains (Strauss and Bradshaw 2004).

While the challenges are great, so are the opportunities. The landscape approach will be an important vehicle to provide countries with implementation packages tailored to a wide range of landscapes and facilitate scaling-up. It will also help to address the interactions, competition, and trade-offs between different land uses and thereby avoid further degradation of land, ecosystems, and forests. Increasing competition for land for agriculture and other uses (Tscharntke et al. 2012) threatens the sustainability of FLR unless accompanied by attention to meeting local needs for food security. Deep and broad knowledge, practical expertise, innovation, and experience exist within the scientific and professional community and within the countless communities living on the front lines of forest landscape degradation, climate change, and other challenges. Enhanced communication and collaboration are needed across forest science disciplines and between the scientific community and land managers, communities, government agencies, NGOs, the private sector, and other organizations and movements operating at local, national, and global levels (Langston et al. 2019).

Acknowledgements The article is an activity within the work of IUFTO Task Force 31 "Forest Adaptation and Restoration under Global Change." Portions of the article are based on presentations made by the authors at the "International Conference on Forest Landscape Restoration under Global Change: Synthesizing and Sharing Globally Available Forest-Related Scientific Knowledge" that was held in San Juan, Puerto Rico, in June 2017, and the report "Implementing Forest Landscape Restoration, A Practitioner's Guide" edited by Stanturf et al. 2017, published by the International Union of Forest Research Organizations, Special Programme for Development of Capacities (IUFRO-SPDC). We acknowledge the contributions of the participants at the conference in Puerto Rico and the support of the staff of the International Institute of Tropical Forestry, US Forest Service, and the Friends of the Karst.

Funding Funding for the conference was provided by the German Federal Ministry for the Environment, Nature Conservation, Building and Nuclear Safety and the IUFRO Special Program on Developing Capacity.

Data availability Data sharing is not applicable to this article as no datasets were generated or analyzed during the current study.

\section{Compliance with ethical standards}

Conflict of interest The authors declare that they have no conflicts of interest.

\section{References}

Aitken SN, Yeaman S, Holliday JA, Wang T, Curtis-McLane S (2008) Adaptation, migration or extirpation: climate change outcomes for tree populations. Evol Appl 1:95-111

Angelsen A et al (2014) Environmental income and rural livelihoods: a global-comparative analysis. World Dev 64:S12-S28

Battisti C (2017) Unifying the trans-disciplinary arsenal of project management tools in a single logical framework: further suggestion for IUCN project cycle development. J Nat Conserv 41:63-72 
Besseau P, Graham S, Christopherson T (eds) (2018) Restoring forests and landscapes: the key to a sustainable future. IUFRO and Global Partnership on Forest and Landscape Restoration, Vienna

Blay D, Appiah M, Damnyag L, Dwomoh FK, Luukkanen O, Pappinen A (2008) Involving local farmers in rehabilitation of degraded tropical forests: some lessons from Ghana. Environ Dev Sustain 10: 503-518

Botman E (2009) Forest rehabilitation in the Republic of Uzbekistan. In: Lee DK, Kleine M (eds) Keep Asia green, West and Central Asia, vol IV. IUFRO World Series, Vienna, pp 253-299

Bradshaw RH (2004) Past anthropogenic influence on European forests and some possible genetic consequences. For Ecol Manag 197:203212

Brancalion PH, Chazdon RL (2017) Beyond hectares: four principles to guide reforestation in the context of tropical forest and landscape restoration. Restor Ecol 25:491-496

Brancalion PH, Viani RA, Calmon M, Carrascosa H, Rodrigues RR (2013) How to organize a large-scale ecological restoration program? The framework developed by the Atlantic Forest Restoration Pact in Brazil. J Sustain For 32:728-744

Breed MF et al (2018) Priority actions to improve provenance decisionmaking. Bioscience 68:510-516

Brockerhoff EG, Jactel H, Parrotta JA, Quine CP, Sayer J (2008) Plantation forests and biodiversity: oxymoron or opportunity? Biodivers Conserv 17:925-951

Brooks N, Adger WN, Kelly PM (2005) The determinants of vulnerability and adaptive capacity at the national level and the implications for adaptation. Glob Environ Chang 15:151-163

Bucharova A, Durka W, Hölzel N, Kollmann J, Michalski S, Bossdorf O (2017) Are local plants the best for ecosystem restoration? It depends on how you analyze the data. Ecol Evol 7:10683-10689

Buckingham K et al (2018) Mapping social landscapes: a guide to restoration opportunities mapping. World Resources Institute, Washington

Charnley S (2017) Forest landscape restoration in West Africa through community forestry: keys to success. Input to IUFRO's International Conference on Forest Landscape Restoration under "Global change - a contribution to the implementation of the Bonn Challenge" in Puerto Rico, 6-9 June 2017. Available online: https://www.iufroorg/download/file/27020/6474/Charnley_poster1 pdf/ (accessed on 13 July 2018)

Chazdon R (2015) Restoring tropical forests: a practical guide. Ecol Restor 33:118-119

Chazdon RL et al (2016) When is a forest a forest? Forest concepts and definitions in the era of forest and landscape restoration. Ambio 45: $538-550$

Cole RJ, Holl KD, Keene C, Zahawi RA (2011) Direct seeding of latesuccessional trees to restore tropical montane forest. For Ecol Manag 261:1590-1597

Cordell S et al (2017) Remote sensing for restoration planning: how the big picture can inform stakeholders. Restor Ecol 25:S147-S154

Crouzeilles R et al (2017) Ecological restoration success is higher for natural regeneration than for active restoration in tropical forests. Sci Adv 3:e1701345

Damnyag L, Saastamoinen O, Appiah M, Pappinen A (2012) Role of tenure insecurity in deforestation in Ghana's high forest zone. Forest Policy Econ 14:90-98

Davis MA et al (2011) Don't judge species on their origins. Nature 474: $153-154$

De Vreese R, Leys M, Fontaine C, Dendoncker N (2016) Social mapping of perceived ecosystem services supply - the role of social landscape metrics and social hotspots for integrated ecosystem services assessment, landscape planning and management. Ecol Indic 66: $517-533$
DeFries RS, Rudel T, Uriarte M, Hansen M (2010) Deforestation driven by urban population growth and agricultural trade in the twenty-first century. Nat Geosci 3:178-181

DeRose RJ, Long JN (2014) Resistance and resilience: a conceptual framework for silviculture. For Sci 60:1205-1212

Dey DC, Gardiner ES, Schweitzer CJ, Kabrick JM, Jacobs DF (2012) Underplanting to sustain future stocking of oak (Quercus) in temperate deciduous forests. New For 43:955-978

Doherty KD, Butterfield BJ, Wood TE (2017) Matching seed to site by climate similarity: techniques to prioritize plant materials development and use in restoration. Ecol Appl 27:1010-1023

Donoso PJ, Soto DP, Coopman RE, Rodríguez-Bertos S (2013) Early performance of planted Nothofagus dombeyi and Nothofagus alpina in response to light availability and gap size in a high-graded forest in the south-central Andes of Chile. Bosque 34:23-32

Donoso P, Soto D, Fuentes C (2015) Differential growth rates through the seedling and sapling stages of two Nothofagus species underplanted at low-light environments in an Andean high-graded forest. New For 46:885-895

Downs A (1972) Up and down with ecology: the "issue-attention cycle". Public Interest 28:38-50

Dumroese RK, Williams MI, Stanturf JA, St Clair JB (2015) Considerations for restoring temperate forests of tomorrow: forest restoration, assisted migration, and bioengineering. New For 46: 947-964

Dumroese KR, Landis TD, Pinto JR, Haase DL, Wilkinson KW, Davis AS (2016) Meeting forest restoration challenges: using the target plant concept. Reforesta 1:37-52

Elliott S (2016) The potential for automating assisted natural regeneration of tropical forest ecosystems. Biotropica 48:825-833

Emer C, Galetti M, Pizo MA, Guimarães PR Jr, Moraes S, Piratelli A, Jordano P (2018) Seed-dispersal interactions in fragmented landscapes - a metanetwork approach. Ecol Lett 21:484-493

Engel VL, Parrotta JA (2001) An evaluation of direct seeding for reforestation of degraded lands in central Sao Paulo state, Brazil. For Ecol Manag 152:169-181

Evans MC (2018) Effective incentives for reforestation: lessons from Australia's carbon farming policies. Curr Opin Environ Sustain 32: $38-45$

Evans K, Guariguata MR, Brancalion PH (2018) Participatory monitoring to connect local and global priorities for forest restoration. Conserv Biol 32:525-534

FAO (2011) Assessing forest degradation - towards the development of globally applicable guidelines. Forest Resources Assessment Working Paper 177. FAO, Rome

Foli E (2017) Land tenure and access to land for forest restoration in Ghana. Input to IUFRO's International Conference on Forest Landscape Restoration under "Global change-a contribution to the implementation of the Bonn Challenge" in Puerto Rico, 6-9 June 2017. Available online: https://www.iufroorg/download/file/ 27699/6474/06_EF_Land_tenure_and_access_to_land-FOLI_v2_ pdf/ (accessed on 13 July 2018)

Freeman OE, Duguma LA, Minang PA (2015) Operationalizing the integrated landscape approach in practice. Ecol Soc 20(1):24 https://doi. org/10.5751/ES-07175-200124

García-Quijano JF, Deckmyn G, Ceulemans R, van Orshoven J, Muys B (2008) Scaling from stand to landscape scale of climate change mitigation by afforestation and forest management: a modeling approach. Clim Chang 86:397-424

Gardiner ES, Yeiser JL (2006) Underplanting cherrybark oak (Quercus pagoda Raf.) seedlings on a bottomland site in the Southern United States. New For 32:105-119

Garibaldi LA, Gemmill-Herren B, D'Annolfo R, Graeub BE, Cunningham SA, Breeze TD (2017) Farming approaches for greater biodiversity, livelihoods, and food security. Trends Ecol Evol 32: $68-80$ 
Gellie NJ, Breed MF, Mortimer PE, Harrison RD, Xu J, Lowe AJ (2018) Networked and embedded scientific experiments will improve restoration outcomes. Front Ecol Environ 16:288-294

Giorgi AP et al (2014) Spatial conservation planning framework for assessing conservation opportunities in the Atlantic Forest of Brazil. Appl Geogr 53:369-376

Grau HR, Aide M (2008) Globalization and land-use transitions in Latin America. Ecol Soc 13 https://www.jstor.org/stable/26267952

Grau HR, Aide TM, Zimmerman JK, Thomlinson JR, Helmer E, Zou X (2003) The ecological consequences of socioeconomic and land-use changes in postagriculture Puerto Rico. AIBS Bull 53:1159-1168

Gutiérrez-Montes I (2017) Livelihoods and integrated planning for FLR. Input to IUFRO's International Conference on Forest Landscape Restoration under "Global change - a contribution to the implementation of the Bonn Challenge" in Puerto Rico, 6-9 June 2017. Available online: https://www.iufroorg/download/file/27023/6474/ Gutierrez_poster-1_pdf/ (accessed on 13 July 2018)

Gutierrez-Montes I, Emery M, Fernandez-Baca E (2009) The sustainable livelihoods approach and the community capitals framework: the importance of system-level approaches to community change efforts. Community Develop 40:106-113

Haase DL, Davis AS (2017) Developing and supporting quality nursery facilities and staff are necessary to meet global forest and landscape restoration needs. Reforesta 4:69-93

Halofsky JE, Creutzburg MK, Hemstrom MA (2014) Integrating social, economic, and ecological values across large landscapes. Gen Tech Rep PNW-GTR-896 Portland, OR: US Department of Agriculture, Forest Service, Pacific Northwest Research Station 206 p 896

Hansen CP (2011) Forest law compliance and enforcement: the case of on-farm timber extraction in Ghana. J Environ Manag 92:575-586

Hansen CP, Lund JF, Treue T (2009) Neither fast, nor easy: The prospect of reduced emissions from deforestation and degradation (REDD) in Ghana. Int For Rev 11:439-455

Harper R, Smettem K, Townsend P, Bartle J, McGrath J (2012) Broadscale restoration of landscape function with timber, carbon and water investment. In: Stanturf J, Lamb D, Madsen P (eds) Forest landscape restoration: integrating social and natural sciences. Springer, New York, pp 275-292

Harper RJ, Sochacki SJ, Smettem KR, Robinson N (2014) Managing water in agricultural landscapes with short-rotation biomass plantations. Glob Change Biol Bioenergy 6:544-555

Harper RJ, Sochacki SJ, McGrath JF (2017) The development of reforestation options for dryland farmland in south-western Australia: a review. South Forests 79:185-196

Hassan R, Scholes R, Ash N (2005) Ecosystems and human well-being: current state and trends, vol 1. Findings of the condition and trends working group of the Millennium Ecosystem Assessment. Island Press, Washington, DC

Hermans-Neumann K, Priess J, Herold M (2017) Human migration, climate variability, and land degradation: hotspots of socio-ecological pressure in Ethiopia. Reg Environ Chang 17:1479-1492

Hobbs RJ (2007) Setting effective and realistic restoration goals: key directions for research. Restor Ecol 15:354-357

Hobbs RJ (2016) Degraded or just different? Perceptions and value judgments in restoration decisions. Restor Ecol 24:153-158

Holden S, Otsuka K, Deininger K (2013) Land tenure reforms, poverty and natural resource management: conceptual framework. In: Holden S, Otsuka K, Deininger K (eds) Land tenure reform in Asia and Africa: assessing impacts on poverty and natural resource management. Palgrave Macmillan, London, pp 1-28

Holger F, Franka H, Ulrike H, Sven W (2015) Developing restoration strategies for temperate forests using natural regeneration processes. In: Stanturf JA (ed) Restoration of boreal and temperate forests, 2nd edn. CRC Press, Boca Raton, pp 103-164

Hughes FMR, Colston A, Mountford JO (2005) Restoring riparian ecosystems: the challenge of accommodating variability and designing restoration trajectories. Ecol Soc $10 \mathrm{https} / / \mathrm{www} . j \mathrm{stor} .0 \mathrm{~g} / \mathrm{stable} /$ 26267745

Hutto RL, Belote R (2013) Distinguishing four types of monitoring based on the questions they address. For Ecol Manag 289:183-189

IPBES (2018) Summary for policymakers of the thematic assessment report on land degradation and restoration of the Intergovernmental Science-Policy Platform on Biodiversity and Ecosystem Services. IPBES Secretariat, Bonn

Iwasa M, Roslan A, Mangsor M (1994) The establishment of multistoried forests in Peninsular Malaysia-underplanting of Dipterocarpaceae in Acacia mangium plantation. In: Proceedings of the International Workshop of BIO-REFOR. BIO-REFOR, Japan, pp. 66-68

Jacobs DF, Dalgleish HJ, Nelson CD (2013) A conceptual framework for restoration of threatened plants: the effective model of American chestnut (Castanea dentata) reintroduction. New Phytol 197:378393

Jalonen R, Valette M, Boshier D, Duminil J, Thomas E (2017) Forest and landscape restoration severely constrained by a lack of attention to the quantity and quality of tree seed: Insights from a global survey Conservation Letters: e12424

Jõgiste K et al. (2017) Hemiboreal forest: natural disturbances and the importance of ecosystem legacies to management Ecosphere 8 e01706

Johnstone JF et al (2016) Changing disturbance regimes, ecological memory, and forest resilience. Front Ecol Environ 14:369-378

Jump AS, Penuelas J (2005) Running to stand still: adaptation and the response of plants to rapid climate change. Ecol Lett 8:1010-1020

Kain M, Battaglia L, Royo A, Carson WP (2011) Over-browsing in Pennsylvania creates a depauperate forest dominated by an understory tree: results from a 60-year-old deer exclosure. J Torrey Bot Soc $138: 322-326$

Kant P, Burns J (2017) Restoring Indian landscapes for multiple purposes. Input to IUFRO's International Conference on Forest Landscape Restoration under "Global change - a contribution to the implementation of the Bonn Challenge" in Puerto Rico, 6-9 June 2017. Available online: https:/www.iufroorg/download/file/27026/6474/ Kant_poster_pdf/ (accessed on 13 July 2018)

Keenan RJ (2015) Climate change impacts and adaptation in forest management: a review. Ann For Sci 72:145-167

Keenleyside K, Dudley N, Cairns S, Hall C, Stolton S (2012) Ecological restoration for protected areas: principles guidelines and best practices. IUCN, Gland

Kegode HJ, Oduol J, Wario AR, Muriuki J, Mpanda M, Mowo J (2017) Households' choices of fuelwood sources: implications for agroforestry interventions in the southern highlands of Tanzania. SmallScale For 16:535-551

Khadka SR, Schmidt-Vogt D (2008) Integrating biodiversity conservation and addressing economic needs: an experience with Nepal's community forestry. Local Environ 13:1-13

Khang DB, Moe TL (2008) Success criteria and factors for international development projects: a life-cycle-based framework. Proj Manag J 39:72-84

Kolstad I, Søreide T (2009) Corruption in natural resource management: implications for policy makers. Resourc Policy 34:214-226

Kusters K, Buck L, de Graaf M, Minang P, van Oosten C, Zagt R (2017) Participatory planning, monitoring and evaluation of multistakeholder platforms in integrated landscape initiatives. Environ Manag 62:170-181

Laarmann D, Korjus H, Sims A, Kangur A, Kiviste A, Stanturf JA (2015) Evaluation of afforestation development and natural colonization on a reclaimed mine site. Restor Ecol 23:301-309

Lamb D, Erskine PD, Parrotta JA (2005) Restoration of degraded tropical forest landscapes. Science 310:1628-1632 
Lamb D, Stanturf J, Madsen P (2012) What is forest landscape restoration? In: Stanturf J, Lamb D, Madsen P (eds) Forest landscape restoration. Springer, Dordrecht, pp 3-23

Langston JD, Riggs RA, Kastanya A, Sayer J, Margules C, Boedhihartono AK (2019) Science embedded in local forest landscape management improves benefit flows to society. Front For Glob Change 19:2. https://doi.org/10.3389/ffgc.2019.00003

Lee DK, Park PS, Park YD (2015) Forest restoration and rehabilitation in the Republic of Korea. In: Stanturf J (ed) Restoration of boreal and temperate forests, 2nd edn. CRC Lewis, Boca Raton, pp 217-231

Liang S, Hurteau MD, Westerling AL (2018) Large-scale restoration increases carbon stability under projected climate and wildfire regimes. Front Ecol Environ 16:207-212

Lillesø J-P et al (2011) Innovation in input supply systems in smallholder agroforestry: seed sources, supply chains and support systems. Agrofor Syst 83:347-359

Louman B (2017) Factors that affect adoption of tree conservation and planting activities in farms in Costa Rica. Input to IUFRO's International Conference on Forest Landscape Restoration under "Global change - a contribution to the implementation of the Bonn Challenge" in Puerto Rico, 6-9 June 2017. Available online: https://www.iufroorg/download/file/27051/6474/14_BL_adoption_ factors_Bastiaan_Louman_pptx/ (accessed on 13 July 2018)

Lugo AE (1997) The apparent paradox of reestablishing species richness on degraded lands with tree monocultures. For Ecol Manag 99:9-19

Lugo AE (2000) Effects and outcomes of Caribbean hurricanes in a climate change scenario. Sci Total Environ 262:243-251

Lugo AE (2018) Characterization of ten extreme disturbance events in the context of social and ecological systems. Biogeochemistry 141: $385-400$

Lugo AE, Erickson HE (2017) Novelty and its ecological implications to dry forest functioning and conservation. Forests 8:161. https://doi. org/10.3390/f8050161

Lugo AE, Helmer E (2004) Emerging forests on abandoned land: Puerto Rico's new forests. For Ecol Manag 190:145-161

Macdonald SE et al (2015) Forest restoration following surface mining disturbance: challenges and solutions. New For 46:703-732

MacKay F, Caruso E (2004) Indigenous lands or national parks? Cultural Survival Quarterly 28:14-16

Madsen P, Jensen FA, Fodgaard S (2005) Afforestation in Denmark. In: Stanturf J, Madsen P (eds) Restoration of boreal and temperate forests. CRC Press, Boca Raton, pp 211-224

Mansourian S (2005) Overview of forest restoration strategies and terms. In: Forest restoration in landscapes. Springer, pp. 8-13

Mansourian S (2016) Understanding the relationship between governance and forest landscape restoration. Conserv Soc 14:267-278

Mansourian S (2017) Governance and forest landscape restoration: a framework to support decision-making. J Nat Conserv 37:21-30

Mansourian S (2018) In the eye of the beholder: reconciling interpretations of forest landscape restoration. Land Degrad Dev 9:2888-2898

Mansourian S, Parrotta J (eds) (2018) Forest landscape restoration: integrated approaches to support effective implementation. Routledge, Earthscan Forest Library

Mansourian S, Stanturf JA, Derkyi MAA, Engel VL (2017) Forest landscape restoration: increasing the positive impacts of forest restoration or simply the area under tree cover? Restor Ecol 25:178-183

MARN (2017) Strengthening the national restoration strategy Ministerio de Medio Ambiente y Recursos Naturales, San Salvador, El Salvador. Available at https://www.iucnorg/sites/dev/files/content/ documents/2017/strengthening_the_national_restoration_strategy_ 12-06-17_v3pdf; last accessed 10 July 2017

Maron $\mathrm{M}$ et $\overline{\mathrm{al}}$ (2012) Faustian bargains? Restoration realities in the context of biodiversity offset policies. Biol Conserv 155:141-148

Martín-López B et al (2017) Delineating boundaries of social-ecological systems for landscape planning: a comprehensive spatial approach. Land Use Policy 66:90-104
Martinuzzi S, Lugo AE, Brandeis TJ, Helmer EH (2013) Case study: geographic distribution and level of novelty of Puerto Rican forests. In: Hobbs RJ, Higgs ES, Hall, CM (eds) Novel ecosystems: intervening in the new ecological world order, Wiley pp. 81-87

Meli P, Holl KD, Benayas JMR, Jones HP, Jones PC, Montoya D, Mateos DM (2017) A global review of past land use, climate, and active vs. passive restoration effects on forest recovery. PLoS One 12: e0171368

Melo FP, Pinto SR, Brancalion PH, Castro PS, Rodrigues RR, Aronson J, Tabarelli M (2013) Priority setting for scaling-up tropical forest restoration projects: early lessons from the Atlantic Forest Restoration Pact. Environ Sci Pol 33:395-404

Metcalf EC, Mohr JJ, Yung L, Metcalf P, Craig D (2015) The role of trust in restoration success: public engagement and temporal and spatial scale in a complex social-ecological system. Restor Ecol 23:315324

Micklin P (2010) The past, present, and future. Aral Sea Lakes Reserv 15: 193-213

MINIRENA (2014) Forest landscape restoration opportunity assessment for Rwanda Ministry Natural Resources Rwanda, IUCN, WRI. Available at http://cmsdata.iucn.org/ downloads/roar_web_version. pdf; last accessed 15 July 2018

Ministry Water and Environment (2016) Forest restoration opportunity assessment report for Uganda Ministry Water and Environment Uganda and IUCN. Available at https://portals.iucn.org/library/ sites/library/files/documents/2016-076.pdf; last accessed 15 July 2018

Minnemeyer S, Laestadius L, Sizer N, Saint-Laurent C, Potapov P (2011) A world of opportunity. World Resource Institute, Washington, DC

Mirzabaev A, Goedecke J, Dubovyk O, Djanibekov U, Le QB, AwHassan A (2016) Economics of land degradation in Central Asia. In: Nkonya E, Mirzabaev A, Von Braun J (eds). Economics of land degradation and improvement - a global assessment for sustainable development, Springer, pp. 261-290

Murdiyarso D, Brockhaus M, Sunderlin WD, Verchot L (2012) Some lessons learned from the first generation of REDD+ activities. Curr Opin Environ Sustain 4:678-685

Nyoka BI et al (2015) Tree seed and seedling supply systems: a review of the Asia, Africa and Latin America models. Small-Scale Forestry 14:171-191

Oliver CD, Covey K, Hohl A, Larsen D, McCarter JB, Niccolai A, Wilson J (2012) Landscape management. In: Stanturf J, Lamb D, Madsen P (eds) Forest landscape restoration. Springer, Dordrecht, pp 39-65

Osborne T, Shapiro-Garza E (2018) Embedding carbon markets: complicating commodification of ecosystem services in Mexico's forests. Ann Am Assoc Geogr 108:88-105

Pagiola S (2008) Payments for environmental services in Costa Rica. Ecol Econ 65:712-724

Palma AC, Laurance SG (2015) A review of the use of direct seeding and seedling plantings in restoration: what do we know and where should we go? Appl Veg Sci 18:561-568

Park MS, Youn Y-C (2017) Reforestation policy integration by the multiple sectors toward forest transition in the Republic of Korea. Forest Policy Econ 76:45-55

Parker WC, Dey DC, Newmaster SG, Elliott KA, Boysen E (2001) Managing succession in conifer plantations: converting young red pine (Pinus resinosa Ait.) plantations to native forest types by thinning and underplanting. For Chron 77:721-734

Parrott L, Meyer WS (2012) Future landscapes: managing within complexity. Front Ecol Environ 10:382-389

Parrotta JA, Knowles OH (2001) Restoring tropical forests on lands mined for bauxite: examples from the Brazilian Amazon. Ecol Eng 17:219-239

Parrotta JA, Turnbull JW, Jones N (1997) Catalyzing native forest regeneration on degraded tropical lands. For Ecol Manag 99:1-7 
Payn T et al (2015) Changes in planted forests and future global implications. For Ecol Manag 352:57-67

Petrokofsky G, Holmgren P, Brown N (2011) Reliable forest carbon monitoring - systematic reviews as a tool for validating the knowledge base. Int For Rev 13:56-66

Pistorius T, Freiberg H (2014) From target to implementation: perspectives for the international governance of forest landscape restoration. Forests 5:482. https://doi.org/10.3390/f5030482

Pistorius T, Carodenuto S, Wathum G (2017) Implementing forest landscape restoration in Ethiopia. Forests 8:61. https://doi.org/10.3390/ f8030061

Platteau JP (2004) Monitoring elite capture in community-driven development. Dev Chang 35:223-246

Puettmann KJ (2014) Restoring the adaptive capacity of forest ecosystems. J Sustain For 33:S15-S27

Putz FE, Redford KH (2010) The importance of defining 'forest': tropical forest degradation, deforestation, long-term phase shifts, and further transitions. Biotropica 42:10-20

Raik DB, Wilson AL, Decker DJ (2008) Power in natural resources management: an application of theory. Soc Nat Resour 21:729-739

Razhapbaev M (2017) Forest landscape restoration in Kyrgyzstan. Input to IUFRO's International Conference on Forest Landscape Restoration under "Global change - a contribution to the implementation of the Bonn Challenge" in Puerto Rico, 6-9 June 2017. Available online: https://www.iufroorg/download/file/27035/6474/ Razhapbaev_Kyrgyzstan_pptx/ (accessed on 13 July 2018)

Reid JL, Wilson SJ, Bloomfield GS, Cattau ME, Fagan ME, Holl KD, Zahawi RA (2017) How long do restored ecosystems persist? Ann Mo Bot Gard 102:258-265

Reid JL, Fagan ME, Zahawi RA (2018) Positive site selection bias in meta-analyses comparing natural regeneration to active forest restoration. Sci Adv 4:eaas9143

Reinecke S, Blum M (2018) Discourses across scales on forest landscape restoration. Sustainability 10:613. https://doi.org/10.3390/ su10030613

Rerkasem K, Yimyam N, Rerkasem B (2009) Land use transformation in the mountainous mainland Southeast Asia region and the role of indigenous knowledge and skills in forest management. For Ecol Manag 257:2035-2043

Robinson BE, Holland MB, Naughton-Treves L (2014a) Does secure land tenure save forests? A meta-analysis of the relationship between land tenure and tropical deforestation. Glob Environ Chang 29:281-293

Robinson K, Bauer J, Lugo AE (2014b) Passing the baton from the Tainos to tomorrow: forest conservation in Puerto Rico, FS-862. US Forest Service, San Juan

Rockström J et al (2017) Sustainable intensification of agriculture for human prosperity and global sustainability. Ambio 46:4-17

Rooney TP, Buttenschøn R, Madsen P, Olesen CR, Royo AA, Stout SL (2015) Integrating ungulate herbivory into forest landscape restoration. In: Stanturf JA (ed) Restoration of boreal and temperate forests, 2nd edn. CRC Press, Boca Raton, pp 69-84

Sacande M, Berrahmouni N (2016) Community participation and ecological criteria for selecting species and restoring natural capital with native species in the Sahel. Restor Ecol 24:479-488

Saha S, Kuehne C, Bauhus J (2016) Lessons learned from oak cluster planting trials in central Europe. Can J For Res 47:139-148

Sayer J et al (2013) Ten principles for a landscape approach to reconciling agriculture, conservation, and other competing land uses. Proc Natl Acad Sci 110:8349-8356

Schwegler J (2017) Rehabilitation of degraded land with native species in Kalimantan. Input to IUFRO's International Conference on Forest Landscape Restoration under "Global change - a contribution to the implementation of the Bonn Challenge" in Puerto Rico, 6-9 June 2017. Available online: https://www.iufroorg/download/file/
27712/6474/25_JS_1706_IUFRO_FLR_Puerto_Rico_ Faierventures_pdf/ (accessed on 13 July 2018)

Silva LN, Freer-Smith P, Madsen P (2018) Production, restoration, mitigation: a new generation of plantations. New For:1-16. https://doi. org/10.1007/s11056-018-9644-6

Smit B, Wandel J (2006) Adaptation, adaptive capacity and vulnerability. Glob Environ Chang 16:282-292

Soto DP, Donoso PJ, Salas C, Puettmann KJ (2015) Light availability and soil compaction influence the growth of underplanted Nothofagus following partial shelterwood harvest and soil scarification. Can J For Res 45:998-1005

Spathelf P, Stanturf J, Kleine M, Jandl R, Chiatante D, Bolte A (2018) Adaptive measures: integrating adaptive forest management and forest landscape restoration. Ann For Sci 75:55. https://doi.org/10. 1007/s13595-018-0736-4

Stanturf JA (2015) Future landscapes: opportunities and challenges. New For 46:615-644

Stanturf JA (2016) Restoring boreal and temperate forests: a perspective. In: Stanturf JA (ed) Restoration of boreal and temperate forests, 2nd edn. CRC Press, Boca Raton, pp 519-534

Stanturf JA, Schoenholtz SH, Schweitzer CJ, Shepard JP (2001) Achieving restoration success: myths in bottomland hardwood forests. Restor Ecol 9:189-200

Stanturf JA, Palik BJ, Dumroese RK (2014a) Contemporary forest restoration: a review emphasizing function. For Ecol Manag 331:292323

Stanturf JA, Palik BJ, Williams MI, Dumroese RK, Madsen P (2014b) Forest restoration paradigms. J Sustain For 33:S161-S194

Stanturf JA, Mansourian S, Kleine M (2017) Implementing forest landscape restoration, a practitioner's guide. International Union of Forest Research Organizations, Vienna, $\mathrm{p} 128$

Stanturf JA, Madsen P, Sagheb-Talebi K, Hansen OK (2018) Transformational restoration: novel ecosystems in Denmark. Plant Biosystems 152:536-546

Strauss SH, Bradshaw HD (2004) The bioengineered forest: challenges for science and society. Resources for the future, Washington DC

Swamy L, Drazen E, Johnson WR, Bukoski JJ (2018) The future of tropical forests under the United Nations Sustainable Development Goals. J Sustain For 37:221-256

Tesfaye MA, Bravo-Oviedo A, Bravo F, Kidane B, Bekele K, Sertse D (2015) Selection of tree species and soil management for simultaneous fuelwood production and soil rehabilitation in the Ethiopian central highlands. Land Degrad Dev 26:665-679

Thevs N, Aliev K (2017) 70 million trees for Kyrgyzstan. Input to IUFRO's International Conference on Forest Landscape Restoration under "Global change - a contribution to the implementation of the Bonn Challenge" in Puerto Rico, 6-9 June 2017. Available online: https:/www.iufroorg/download/file/27039/6474/ Thevs_poster_pdf/ (accessed on 13 July 2018)

Thomas E et al (2014) Genetic considerations in ecosystem restoration using native tree species. For Ecol Manag 333:66-75

Tobón W et al (2017) Restoration planning to guide Aichi targets in a megadiverse country. Conserv Biol 31:1086-1097

Tscharntke T et al (2012) Global food security, biodiversity conservation and the future of agricultural intensification. Biol Conserv 151:5359

UNCCD (ed) (2017) Global land outlook. UN Convention to Combat Desertification, Bonn

Uprety Y, Asselin H, Bergeron Y, Doyon F, Boucher J-F (2012) Contribution of traditional knowledge to ecological restoration: practices and applications. Ecoscience 19:225-237

van Noordwijk M, Suyamto DA, Lusiana B, Ekadinata A, Hairiah K (2008) Facilitating agroforestation of landscapes for sustainable benefits: tradeoffs between carbon stocks and local development benefits in Indonesia according to the FALLOW model. Agric Ecosyst Environ 126:98-112 
van Oosten C (2013) Restoring landscapes - governing place: a learning approach to forest landscape restoration. J Sustain For 32:659-676

Vargas RG (2017) Systematizing forest restoration through trials in South-Central Chile: two examples. Input to IUFRO's International Conference on Forest Landscape Restoration under "Global change - a contribution to the implementation of the Bonn Challenge" in Puerto Rico, 6-9 June 2017. Available online: https://www.iufroorg/download/file/27040/6474/Vargas_poster_ pdf/ (accessed on 13 July 2018)

Veldman JW et al (2015) Tyranny of trees in global climate change mitigation. Science 347:484-485

Verdone M, Seidl A (2017) Time, space, place, and the Bonn Challenge global forest restoration target. Restor Ecol 25:903-911

Viani RA, Barreto TE, Farah FT, Rodrigues RR, Brancalion PH (2018) Monitoring young tropical forest restoration sites: how much to measure? Tropical Conservation Science. https://doi.org/10.1177/ 1940082918780916

Vittek M, Brink A, Donnay F, Simonetti D, Desclée B (2014) Land cover change monitoring using Landsat MSS/TM satellite image data over West Africa between 1975 and 1990. Remote Sens 6:658-676

Wardell DA, Lund C (2006) Governing access to forests in northern Ghana: micro-politics and the rents of non-enforcement. World Dev 34:1887-1906

Wells MP, McShane TO (2004) Integrating protected area management with local needs and aspirations. AMBIO 33:513-519

Worbes M, Botman E, Khamzina A, Tupitsa A, Martius C, Lamers JPA (2006) Scope and constraints for tree planting in the irrigated landscapes of the Aral Sea Basin: case studies in Khorezm Region, Uzbekistan. ZEF Discussion Papers on Development Policy, No.
112, University of Bonn, Center for Development Research (ZEF), Bonn

Wunder S, Engel S, Pagiola S (2008) Taking stock: a comparative analysis of payments for environmental services programs in developed and developing countries. Ecol Econ 65:834-852

Wunderle JM Jr (1997) The role of animal seed dispersal in accelerating native forest regeneration on degraded tropical lands. For Ecol Manag 99:223-235

Zhai D-L, Xu J-C, Dai Z-C, Cannon CH, Grumbine R (2014) Increasing tree cover while losing diverse natural forests in tropical Hainan, China. Reg Environ Chang 14:611-621

Zomer RJ et al (2016) Global tree cover and biomass carbon on agricultural land: the contribution of agroforestry to global and national carbon budgets. Sci Rep 6:29987. https://doi.org/10.1038/ srep29987

Zoveda F (2017) Towards harmonized and cost-effective monitoring frameworks for FLR: joining efforts through the collaborative roadmap. Input to IUFRO's International Conference on Forest Landscape Restoration under "Global change - a contribution to the implementation of the Bonn Challenge" in Puerto Rico, 6-9 June 2017. Available online: https://www.iufroorg/download/file/ 27704/6474/10_FZ_Monitoring_Roadmap_IUFRO_20170605_ pdf/ (last accessed 13 July 2018)

Publisher's note Springer Nature remains neutral with regard to jurisdictional claims in published maps and institutional affiliations. 